Article

\title{
Corporate Social Responsibility of Water and Sanitation Company in the Czech Republic-Case Study
}

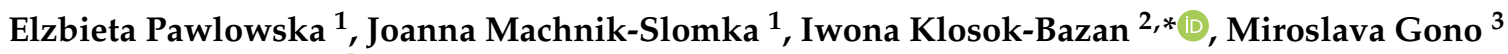 \\ and Radomir Gono ${ }^{3}$ (D)
}

Citation: Pawlowska, E.;

Machnik-Slomka, J.; Klosok-Bazan, I.; Gono, M.; Gono, R. Corporate Social Responsibility of Water and Sanitation Company in the Czech Republic-Case Study. Energies 2021, 14, 3981. https://doi.org/10.3390/ en14133981

Academic Editor: Sergey Zhironkin

Received: 31 May 2021

Accepted: 28 June 2021

Published: 2 July 2021

Publisher's Note: MDPI stays neutral with regard to jurisdictional claims in published maps and institutional affiliations.

Copyright: (C) 2021 by the authors Licensee MDPI, Basel, Switzerland. This article is an open access article distributed under the terms and conditions of the Creative Commons Attribution (CC BY) license (https:// creativecommons.org/licenses/by/ $4.0 /)$
1 Institute of Management and Logistics, Faculty of Organization and Management, Silesian University of Technology, Roosevelta 26, 41-800 Zabrze, Poland; elzbieta.pawlowska@polsl.pl (E.P.); joanna.machnik-slomka@polsl.pl (J.M.-S.)

2 Department of Thermal Engineering and Industrial Facilities, Faculty of Mechanical Engineering, Opole University of Technology, Mikolajczyka 5, 45-271 Opole, Poland

3 Department of Electrical Power Engineering, Faculty of Electrical Engineering and Computer Science, VSB-Technical University of Ostrava, 17. listopadu 2172/15, 70800 Ostrava, Czech Republic; miroslava.gono@vsb.cz (M.G.); radomir.gono@vsb.cz (R.G.)

* Correspondence: i.klosok-bazan@po.edu.pl; Tel.: +48-77-449-8882

\begin{abstract}
The issue discussed in this article concerns corporate social responsibility (CSR), which is playing an increasingly important role in the context of sustainable development of enterprises. The purpose of the current work was to assess the practices applied in the area of corporate social responsibility in water and sanitation companies, based on the opinions of employees and managers. The motivation for undertaking research on this topic resulted from the scarcity of scientific studies on the measurement of the corporate social responsibility concept in water and sanitization companies using a multidimensional approach based on the ISO 26000 standard. The study used methodological triangulation based on the use of qualitative and quantitative research methods to verify information from different sources. This approach allowed the authors to obtain the data more effectively and analyze the problem from numerous different perspectives. The study used an interview method that targeted water and sanitization utility staff. In-depth research was based on the case study method, which is particularly important when researching complex phenomena. For this purpose, surveys were carried out, the results of which indicate that corporate social responsibility of the surveyed enterprise is at a high level, and that there are statistically significant differences between individual dimensions of CSR. The results indicate that the surveyed company is oriented towards supporting activities in the area of corporate social responsibility, in accordance with the in the concept of sustainable development.
\end{abstract}

Keywords: corporate social responsibility (CSR); sustainable development; water and sanitation company sector

\section{Introduction}

The concept of corporate social responsibility (CSR) is playing an increasingly important role in the context of companies' aspirations for sustainable development [1,2], which is seen as an important paradigm in the field of management and quality sciences. The concept of sustainable development is increasingly relevant because due to technological progress, among other factors, economies use environmental resources by building capital, thereby increasing social development and improving the quality of life [3]. In relation to sustainable development, the concept of CSR relates to maintaining a balance between activities aimed at the achievement of objectives with ecological, social, and economic aspects [4]. CSR focuses on the effort of enterprises to achieve not only economic goals, but to balance them with social and environmental goals [5-7]. Although CSR is not a new concept, due to the growing problems associated with environmental pollution, social 
challenges, and globalization processes, the interest in the concept has grown. Corporate social responsibility, hereinafter referred to as CSR, is currently of great interest to both researchers and practitioners [8]. This is an under-recognized area with a significant impact on situations inside and outside of organizations [9].

In CSR research, the focus is increasingly given to means of promoting the concept in companies and extending the theory based on a multidimensional approach, which is interestingly reflected in the CSR concept [7]. For these reasons, the concept of CSR research is based on the ISO 26000 standard, thus extending the conventional assessment, which is usually one- or two-dimensional.

Theoretical and cognitive analysis has identified deficiencies in research on the concept of social responsibility using a multidimensional approach based on the ISO 26000 standard. This cognitive gap is reflected in the research gap related to the perception of corporate social responsibility by employees and managers in enterprises of the water and sanitation sector. Additionally, the focus of research on this type of enterprise was due to researchers' conviction regarding the enterprises' conservative approach to contemporary concepts of management, or certain conservative mental patterns. The conducted literature analysis did not reveal research on this topic in the context of water and sanitation enterprises. Albuquerque, Koskinen and Zhang [10] surmise that the growing interest in the CSR concept by companies has not kept pace with the research needed to justify it.

To fill the identified gaps, the objective of the study was formulated: to assess the practices applied in the area of the concept of corporate social responsibility of enterprises in the water and wastewater sector, based on the opinions of employees and managers. For enterprises in the water and sanitation sector, the CSR concept is particularly important for several reasons. First, it stems from the specificity and role of the activities of these enterprises for the benefit of society by providing water in a safe and responsible manner [11]. In addition, it is a concept that can strengthen the social credibility and confidence of society and an enterprise's customers. This is particularly important given the importance of water, including its quality, which has a high value for society and life. This concept also has an impact on shaping appropriate attitudes and behaviors of the employees of these companies, who should be focused not only on achieving the company's objectives and economic results, but also on social and environmental effects, by taking care of protection against these effects and counteracting any threats that may occur. Due to the focus of these companies, their activities affect the lives of the vast majority of a region's residents: both customers who consume drinking water and those who discharge pollutants into the sewer system, but also company employees and suppliers of materials, technology, and services.

The paper formulates research questions and hypotheses, which were verified through empirical research. The main research problem focuses on the answer to the question: how is corporate social responsibility shaped in water and sanitary companies in the opinion of employees and managers? The research presented in this article is an answer to the cognitive and research gap identified in the literature on the subject, in relation to the assessment that allows examination of the level of CSR, and the relationship between the various dimensions of the CSR concept. The research carried out included a diagnosis of managers' and employees' perceptions of corporate social responsibility in seven dimensions, i.e., organizational governance, human rights, labor practices, environment, fair operating practices, consumer issues, social commitment, and community development [12]. The results of the research confirmed, among other things, the assumed high level of the assessed CSR concept in relation to the examined enterprise.

\section{Corporate Social Responsibility Literature Review}

To date, the literature on the subject has not reached a single unambiguous definition of this concept, and various approaches to it have been proposed, which are often inconsistent with one another [13,14]. Table 1 summarizes some selected illustrative definitions of CSR. 
Table 1. Definitions of corporate social responsibility (CSR).

\begin{tabular}{cl}
\hline Source & \multicolumn{1}{c}{ Definitions } \\
\hline Carroll [15] & $\begin{array}{l}\text { "encompasses the economic, legal, ethical and discretionary } \\
\text { expectations that society has of organizations at a given point } \\
\text { in time" } \\
\text { "considering the social and environmental impact of a } \\
\text { company's activities when making operational decisions" } \\
\text { "the practice of going beyond regulation to effectively balance } \\
\text { commitments to investors, customers, other businesses and } \\
\text { other communities" } \\
\text { "the responsibility of an organization for the impacts of its } \\
\text { decisions and activities on society and the environment, } \\
\text { through transparent and ethical behaviour" } \\
\text { "set of responsibilities incumbent on an organization to protect } \\
\text { and enhance the community in which it operates" }\end{array}$ \\
ISO 26000 [18] & Griffin [19]
\end{tabular}

In the opinion of Carroll, whose work was a breakthrough and aroused significant interest in the scientific community, the nature of social responsibility can be divided into, among others dimensions, ethical, legal, economic, and discretionary responsibilities $[15,20]$. The concept of social responsibility is perceived by many authors as the process of creating and developing relations with stakeholders of a given enterprise, thus contributing to its development and success [20-24]. It is therefore of importance in the economic world [25]. As emphasized by Usman and Amran [26], for companies to be successful and gain a competitive advantage they must act ethically towards all of their stakeholders. A similar position is presented by Stojanovic et al. [27], Habek and Wolniak [28], and Čierna and Sujová [29]. Therefore, CSR also appears in the awareness of many managers to be a concept that is increasingly important in achieving success, by creating value for all of its stakeholders who influence or are influenced by the company's activities [30,31]. Therefore, to achieve long-term success, a company should be based on ethical values, and respect for people and the environment [32]. Wu et al. [33] emphasize that CSR is a multi-dimensional concept that reflects a comprehensive representation of a company's competitiveness. In this context, ecological innovations in companies are increasingly important [34]. As indicated by van Beurden and Gössling [35], this concept can also affect the financial efficiency of enterprises. The systems approach of companies, which is increasingly emphasized in the literature, is important in this respect [36]. Therefore, many managers attach increasing importance to the recognition and implementation of CSR practices [1]. In this respect, it is important to be able to effectively manage relations with stakeholders of a given enterprise, based on trust [37,38]. A detailed analysis of the definition of corporate social responsibility indicates five important domains associated with the concept. These are stakeholder orientation, social character, and voluntariness, in addition to environmental and economic character. This underlines the multidimensional nature and complexity of the construct of corporate social responsibility.

An interesting definition of corporate social responsibility, which underlines its multidimensional character, is that included in ISO 26000. This standard states that social responsibility can be understood as "the responsibility of an organization for the impact of its decisions and activities on society and the environment, through transparent and ethical behavior that: contributes to sustainable development, including the health and wellbeing of society; takes into account the expectations of stakeholders (individuals or groups who have an interest in the decisions or actions of the organization); complies with applicable law and is consistent with international standards of conduct; is integrated into and practiced in the organization's operations, which relate to the organization's activities within its sphere of influence" [18].

The standard is therefore not only aimed at profit-oriented enterprises, but also at public organizations. Importantly, ISO 26000 is not a management system standard. However, it contains elements which may be incorporated into already existing systems: 
quality management (ISO 9001), environmental management (ISO 14001), and occupational health and safety management (OHSAS 18001/ PN-N-18001). According to ISO 26000, the CSR concept is based upon seven areas, i.e., organizational governance, human rights, labor practices, environment, fair operating practices, consumer issues, community involvement, which correlate with sustainable development. This is illustrated in Figure 1. According to ISO 26000 [12]:

- Organizational governance is the system through which an organization makes and implements decisions to achieve its goals.

- Human rights are realized through the organization's due diligence in identifying and preventing actions that violate human rights or the dignity of individuals.

- Labor practices are understood to include the employment of employees under employment or other civil law contracts, in addition to working conditions, social dialogue, employee development and safety of employees.

- Environment is concerned with efforts to reduce the burden on the environment through efficient use of resources, energy conservation, waste reduction, and commitment to environmental protection in compliance with national and EU regulations.

- Fair operating practices - based on the implementation of anti-corruption mechanisms, in addition to the organization's activities that comply with regulations on preventing unfair market practices.

- Consumer issues - based on honest marketing, reliable and objective information, and fair practices. Providing products and services that are safe and do not involve an unacceptable risk of harm during use or consumption, in addition to an orientation towards educating stakeholders in the area of informed and responsible consumption behavior, and support related to complaints and dispute resolution.

- Community involvement by hiring community workers, creating jobs, and developing skills. Consultation with local community groups on investments and community development activities, and active participation in local development by supporting schools, associations, and charities in the area where the company operates.

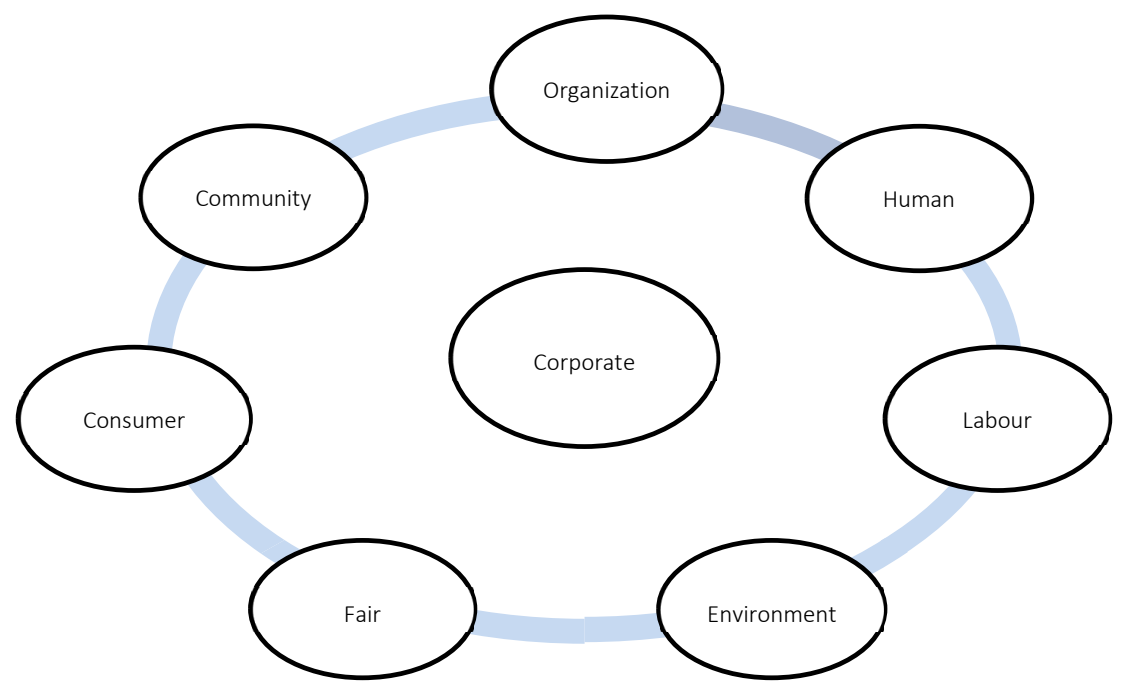

Figure 1. A multidimensional approach of CSR according to ISO 26000 own elaboration on [12].

Corporate social responsibility can be analyzed from both internal and external perspectives [39,40]. Analysis of CSR from an internal perspective is based on organizational practices that contribute to increased employee satisfaction with employment in a given organization, taking into account such areas as job security, respect for human rights, equal opportunities for women and men in terms of jobs and wages, and the ongoing development of employees [41,42]. By comparison, the analysis of CSR from an external perspective takes into account the social initiatives of an organization that contribute to strengthening 
its reputation among external stakeholders, including: following best practices, rational management of natural resources and waste, popularizing pro-environmental ideas, or reducing the negative impact of enterprises on the environment [43].

Based on theoretical and cognitive analysis, it can be concluded that corporate social responsibility can be understood as a long-term strategy of the organization, oriented towards supporting activities for a cleaner environment, economic development, and a better society, taking into account the expectations of various groups of stakeholders, thus contributing to sustainable development [44]. The issue of measuring corporate social responsibility is a relatively new area of research that is not fully recognized. In the literature, one can distinguish many general concepts and methods of measurement, measures, and research indicators [45]. The construct of corporate social responsibility is measurable both in profit-oriented and non-profit organizations, such as water and sanitization companies. Analysis of various means of measuring CSR indicates that this concept is an area that is difficult to quantify [46]. This difficulty results from the variety of definitions and interpretations of the concept. Therefore, a single unambiguous tool that could be used for the diagnosis and assessment of CSR has not been presented in the literature. Furthermore, such a diagnosis is highly important, because, referring to the opinion of Coopers \& Deloitte, organizations of various sizes that examine CSR and undertake CSR activities, and improve them in the long term, achieve a significant advantage over their less aware competitors [47]. Therefore, to fill the diagnosed gap, the authors undertook to develop a tool to examine CSR using a multidimensional approach.

\section{Materials and Methods}

The presented research is part of an extensive research process implemented by an interdisciplinary research team. The research process is composed of the following stages: theoretical cognitive research, identification of a cognitive gap, qualitative research conducted in 10 purposefully selected water and sanitization enterprises, formulation of research hypotheses, and verification of research hypotheses within the framework of in-depth quantitative research.

Based on the main objective of the study, the following specific objectives were formulated:

- $\quad$ to identify the role of CSR in the development of enterprises in the water and wastewater sector;

- construction of a research model and conceptualization of CSR dimensions in the research model;

- $\quad$ creation of instruments for measurement and assessment of CSR;

- $\quad$ empirical verification of the research hypotheses.

The theoretical-cognitive research used the methodology of a systematic literature review, which was the basis for the appropriate formulation of questions and research hypotheses, in addition to the interpretation of the results obtained from the empirical research [48]. Based on the theoretical-cognitive research, a gap was identified that reflected the deficiency of scientific research on CSR using a multidimensional approach, based on the international standard ISO 26000 in water and sanitization companies. The analysis of the concepts and the ISO 26000 standard in the field of corporate social responsibility made it possible to identify its individual dimensions, on the basis of which the model was built and verified. Based on the analysis of the literature on the subject, a gap connected with CSR measurement tools was identified. Thus, the authors attempted to create a tool to measure this construct based on a detailed analysis of the ISO 26000 standard. A survey questionnaire was developed that enabled the measurement of corporate social responsibility in water and sanitization companies. The authors chose ISO 26000 as the basis for the survey questionnaire due to its transparency, international context, and the recommendations of the European Commission as a key document in the implementation of social responsibility. In the research process, methodological triangulation was applied, using first qualitative research, and then quantitative research. Both qualitative and quantitative research focused on the main research problem formulated in the form of the 
following question: how is corporate social responsibility shaped in water and wastewater enterprises, in the opinion of employees and managers?

Two research tools were used in the study. For the qualitative research, the study was conducted using a non-standardized, free-form interview questionnaire. The quantitative research used a standardized questionnaire with a five-point Likert scale.

As part of the qualitative research, unstructured interviews were conducted with 10 managers from 10 different water and sanitization companies. Those interviewed included top and middle level managers who led different departments, such as technical, operations, supply, and employee affairs.

In the Czech Republic, as an effect of the privatization process, fragmentation of the water and sanitization company has taken place. Before the system change, only 11 public water companies were operating. The database of the Ministry of Agriculture shows a total of 6668 owners and 2853 operators throughout the Czech Republic. Owners are, for example, municipalities or voluntary associations of municipalities [49].

As part of the qualitative research, unstructured interviews were conducted with 10 managers of purposefully selected water and sanitization enterprises. These interviews were aimed at identifying the opinions regarding CSR and its practices in water and wastewater enterprises, with a focus on the main research problem. These interviews also served to formulate research hypotheses for in-depth quantitative research, and then to verify the correctness of the developed research tool in the form of a standardized questionnaire survey.

The case study method was chosen to conduct the in-depth research. This method enables empirical conclusions to be drawn regarding the analysis of a given phenomenon in its natural context, which is of particular importance when the border between a case and its context cannot be unambiguously defined [50]. The study provided the authors with an empirical, in-depth insight into the specifics of corporate social responsibility of a purposefully selected water and sanitization company operating in the Czech Republic. Yin recommends the use of the case study method in the search for answers to questions of an exploratory nature, and to explain "how?" and "why?" a given phenomenon exists [50].

In relation to the research problem defined on the basis of the literature analysis and conclusions resulting from the qualitative research, the following specific research questions were formulated:

1. How is corporate social responsibility shaped in a water and sewage company?

2. How is the level of development of individual dimensions of the CSR construct shaped? Is the development of these dimensions even or different?

3. Are there differences in the assessment of individual dimensions of CSR between managers and employees?

4. Is seniority an important factor influencing perception of social responsibility?

In the search for answers to the research questions, the following research hypotheses were formulated:

Hypotheses 1 (H1). Corporate social responsibility of the company is at a high level in the opinion of employees and managers.

Hypotheses 2 (H2). There are statistically significant differences between different dimensions of CSR.

Hypotheses 3 (H3). There are statistically significant differences in the evaluations of the level of CSR by managers and employees.

Hypotheses 4 (H4). A control variable such as working experience affects the level of perception of employees and managers of a company with respect to CSR.

The formulated research questions and hypotheses resulted from the conducted theoretical and qualitative research. The analysis shows that water supply and sanitization companies are a special type of enterprises that implement and provide services related to the supply of water to residents, in addition to the treatment and disposal of sewage. The 
mission of water and sanitization companies, unlike other profit-oriented companies, is to serve the local community. Therefore, aspects related to sustainable development and CSR are particularly important for them. As the results of the conducted research show, these companies are increasingly implementing and realizing CSR principles. The present research focuses on the mechanism of the formation of CSR perceptions in water companies, highlighting the possibility of examining whether the level of development of individual CSR sub-dimensions is occurring in a harmonious manner, or whether there are significant differences between them. This opens up a new framework for in-depth research on CSR. The importance of researching the impact of different degrees of CSR in companies is highlighted by Chung-Hua et al. [51]. The importance and methods of measuring CSR are also highlighted by Hąbek [52]. An illustration of the research hypotheses is the research model illustrated in Figure 2.

H 1

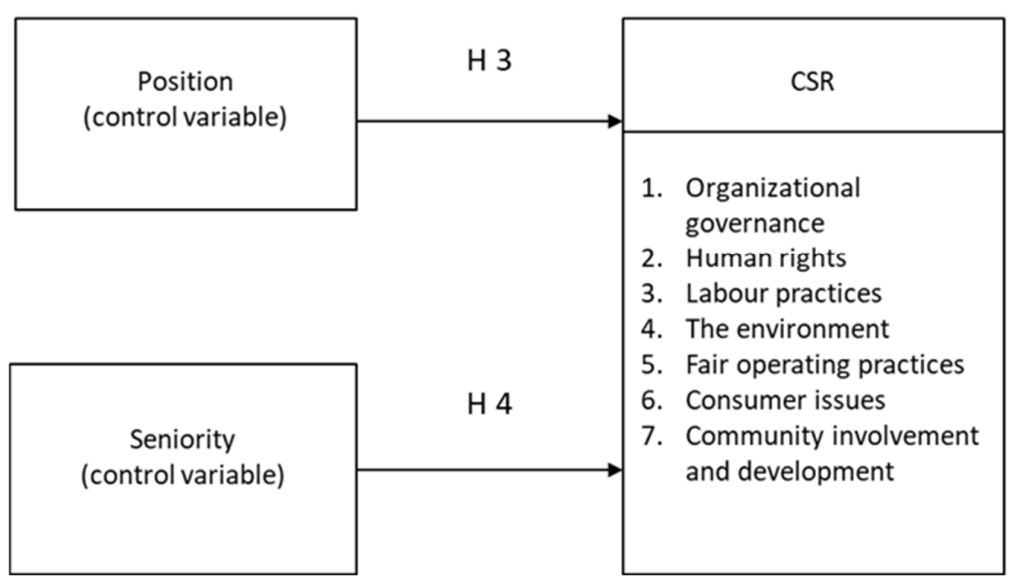

$\mathrm{H} 2$

Figure 2. Graphical presentation of research method conception [own elaboration].

Based on the research model, to verify the hypotheses in the paper, a survey of corporate social responsibility was conducted among both employees and managers, and the relationship of control variables such as position held and seniority in relation to CSR was identified. Quantitative research was conducted in a water and sanitization company in the Czech Republic. The choice of this particular company was based on the fact that it has a very comprehensive organizational structure. The surveyed company employs over 800 people and is a producer and supplier of water, which reaches over 700,000 inhabitants of the region. In addition, the company treats wastewater in several dozen wastewater treatment plants, thus returning more than $270,000 \mathrm{~m}^{3}$ to the environment each day. Almost 100,000 inhabitants of the region use the services of the company, which, in accordance with its CRS policy, declares that it is aware of its responsibility for the future of the region in which it operates. The concept of social responsibility and sustainable development is an integral part of the company's existence that runs through all areas of its activities.

As part of the in-depth quantitative research and to ensure proper reliability of the research, other sources of data were also used, such as source documents-information contained on the official website of the researched company, in addition to the company's strategy and other reports and strategic documents.

The research was conducted using a standardized questionnaire survey, based on the Computer Assisted Web Interview (CAWI) method, which consists of collecting data and information in an electronic form. An invitation with a link to the survey was sent to all employees of the surveyed company. The contents of the questions posted from the research questionnaire are shown in Tables 3 and 4. The research was conducted in January 2021. The research tool used a ranking of positive phenomena using a five-point Likert scale that allowed ranking the level of perception of the enterprise's employees towards corporate social responsibility. This allowed determination of the level of corporate social 
responsibility that exists in the studied enterprise. When assessing the level of corporate social responsibility in terms of the arithmetic mean, the following interpretation was adopted for individual values:

arithmetic average $=1$-the level of CSR is very low,

arithmetic average $=2$-the level of CSR is low,

arithmetic average $=3$-the level of CSR is average,

arithmetic average $=4$ - the level of CSR is high,

arithmetic average $=5$ - the level of CSR is very high.

The questionnaire was used as the main method of data collection in the surveyed water supply and sanitization company $(n=145)$ to research perceptions about the dimension of corporate social responsibility. The respondents were managerial staff $(n=46)$ and operational level employees $(n=99)$. They included managers and employees from different departments: wastewater, water, planning and supervision, organizational, project implementation, sales, support, control, and audit. A total of 150 questionnaires were received. After their verification, 5 questionnaires were rejected due to the lack of completeness of the data obtained.

Statistical analysis methods were used to analyze the collected data. The program STATISTICA and the spreadsheet MS Excel were used. A factor analysis was conducted to verify the correctness of the selection of variables describing individual dimensions of corporate social responsibility. Factor analysis was preceded by calculating the value of the Kaiser-Meyer-Olkin measure (KMO) of the adequacy of the selection of input variables for factor analysis and conducting Bartlett's test of sphericity. The basis for selecting the number of factors was based on Kaiser's criterion for accepting factors that have eigenvalues greater than 1 . It was assumed that the variables for which the factor loadings with each of the determined factors were less than 0.6 were removed from the group of variables describing the CSR dimension. The reliability of the scale for each factor was assessed by the value of Cronbach's coefficient. The minimum reliability of the scale was determined by a Cronbach's coefficient value greater than 0.6 [53].

$$
\alpha=\frac{N \cdot \bar{r}}{1+(N-1) \cdot \bar{r}}
$$

where:

$\bar{r}$-average correlation coefficient

$N$-sample size

To verify Hypotheses $1(\mathrm{H} 1)$ and 3 (H3), descriptive statistics were analyzed and the hypothesis of normality of the CSR distribution was tested using the chi square test. To verify Hypotheses $2(\mathrm{H} 2)$ and 4 (H4), a non-parametric alternative one-way analysis of variance was conducted using the Kruskal-Wallis test.

\section{Results}

According to the research methodology and procedure, qualitative research using the interview method with managers of water supply companies, and in-depth quantitative research based on the case study method, of a purposively selected water supply company operating in the Czech Republic, were conducted. The results are presented in this section.

The interviews showed that an increasing number of water and wastewater companies, and particularly larger companies, are taking increasingly active steps in the area of CSR. This is manifested by the development by these enterprises of corporate social responsibility strategies, building relationships between the company and its local environment based on the principles of corporate social responsibility, and undertaking social and charity campaigns. These enterprises are implementing increasing pro-ecological undertakings and actions to educate various groups of stakeholders regarding the environment and health protection. 
Companies emphasize that, in the face of contemporary challenges faced by water and sanitation companies, it is increasingly important to form appropriate relationships with stakeholders and be socially responsible towards them. It is therefore important to invest in human resources and environmental protection, which contributes to increasing the competitiveness of the company and shaping the conditions for sustainable development for the benefit of society.

This is particularly important for the companies in the sector we analyzed because of their social mission.

The surveyed managers stressed the increasing need to implement environmental protection activities, including effective waste management, and to support environmental awareness of stakeholders. Managers also stressed the importance of creating values related to ethical behavior towards stakeholders, both internal and external, in addition to respect, honesty, and a focus on development and implementation of eco-innovations. The interviews conducted with managers indicate an increase in the awareness of water companies regarding the need to implement sustainable development projects. The research emphasized that undertaking CSR activities is the result of maturity and responsibility of the company towards society and all other stakeholders.

On the basis of quantitative research, to verify the validity of the selection of variables describing individual dimensions of corporate social responsibility, factor analysis was used. The factor analysis was preceded by calculating the Kaiser-Meyer-Olkin (KMO) measure and conducting Bartlett's test of sphericity. The results of these analyses are presented below.

This was followed by Bartlett's test of sphericity, which assumes that the matrix of correlation coefficients is a unitary matrix, i.e., there are no significant correlations between the variables.

The values of the KMO measure and the results of Bartlett's test of sphericity for individual dimensions of corporate social responsibility are included in Table 2.

According to Kaiser's criterion, the analyzed dimensions were assumed to be univariate constructs. The factor loadings for each of the seven CSR dimensions are presented in Table 3.

The data in Table 3 shows that the defined factor for:

- $\quad$ organizational governance dimension explains $60.08 \%$ of the initial variance of the variables and Cronbach's $\alpha$ coefficient for the scale analyzed was 0.825 ;

- $\quad$ human rights dimension explains $69.78 \%$ of the initial variance of the variables and Cronbach's $\alpha$ coefficient for the scale analyzed was 0.908 ;

- labor practices dimension explains $62.52 \%$ of the initial variance of the variables and Cronbach's $\alpha$ coefficient for the scale analyzed was 0.820 ;

- $\quad$ environment dimension explains $69.17 \%$ of the initial variance of the variables and Cronbach's $\alpha$ coefficient for the scale analyzed was 0.844 ;

- $\quad$ fair operating practices dimension explains $73.45 \%$ of the initial variance of the variables and Cronbach's $\alpha$ coefficient for the scale analyzed was 0.877 ;

- consumer issues dimension explains $69.37 \%$ of the initial variance of the variables and Cronbach's $\alpha$ coefficient for the scale analyzed was 0.849 ;

- community involvement dimension explains $64.76 \%$ of the initial variance of the variables and Cronbach's $\alpha$ coefficient for the scale analyzed was 0.862 .

In summary, as the analysis shows, all dimensions of the CSR construct were univariate. Removing any variable from each of the seven CSR dimensions would not increase the values of the individual Cronbach's $\alpha$ coefficients.

As a result of the research, the formulated hypotheses were verified, the justification and description of which is given below.

Hypotheses 1 (H1). Corporate Social Responsibility of the company is at a high level in the opinion of employees and managers. 
To verify hypothesis 1 (H1) assuming that the level of corporate social responsibility of the company and its individual dimensions is at a high level, descriptive statistics were analyzed, as presented in the table below.

The data presented in Table 4 show that the highest average values indicated by the arithmetic mean pertain to the organizational governance dimension (4.17), followed by the consumer issues dimension (4.16), and at a slightly lower level, fair operating practices (4.15), labor practices (4.10), and the human rights dimension (4.07). In contrast, the lowest level is the environment dimension (3.94), followed by community involvement and development (3.58). The results are presented in the chart below.

To analyze the responses in detail and identify differences between them, individual dimensions of corporate social responsibility were analyzed. The corporate social responsibility dimension (Figure 3) of organizational governance, particularly dimension O_1.2. concerning the existence of a code of ethical conduct in the company (4.61) is at the highest level. The value of this dimension indicates that employees are aware of the existence of such a document in the company, so it is known and respected by them. A slightly lower rating was given to dimension $\mathrm{O}_{-}$1.3. indicating that the company respects the regulations of national international law (4.41). Currently, all enterprises must operate based on legal norms, and the conducted research shows that the examined enterprise realizes this. Dimension O_1.4 concerning company's orientation towards stakeholders' needs (4.03) was rated slightly lower, although it can still be said that the level of this dimension is relatively high. This proves that the company cooperates with various groups of stakeholders, taking into account their rights and expectations. Slightly lower scores were given to dimension O_1.5. indicating that managers play an important role in motivating employees (3.90), and dimension O_1.1. indicating the existence of a transparent decision-making process in the company and the transmission of information about it (3.89). These results indicate that the weaker links in the organization are the competencies of managers in motivating employees and informing them about the decisions made and the factors influencing these decisions.

Table 2. KMO measure and Bartlett's test of sphericity results for CSR dimensions [Source: Own survey result].

\begin{tabular}{|c|c|c|c|c|c|c|c|}
\hline \multirow{4}{*}{$\begin{array}{l}\text { 1.Ornizational } \\
\text { governance }\end{array}$} & \multicolumn{2}{|c|}{$\begin{array}{c}\text { Kaiser-Meyer-Olkin Measure of } \\
\text { Sampling Adequacy }\end{array}$} & \multirow{2}{*}{$\begin{array}{c}0.746 \\
314.665\end{array}$} & \multirow{4}{*}{ 2. Human rights } & \multicolumn{2}{|c|}{$\begin{array}{l}\text { Kaiser-Meyer-Olkin Measure of } \\
\text { Sampling Adequacy }\end{array}$} & \multirow{2}{*}{$\begin{array}{c}0.887 \\
558.354\end{array}$} \\
\hline & \multirow{3}{*}{$\begin{array}{l}\text { Bartlett's Test of } \\
\text { Sphericity }\end{array}$} & $\begin{array}{l}\text { Approx. } \\
\text { Chi-Square }\end{array}$ & & & \multirow{3}{*}{$\begin{array}{l}\text { Bartlett's Test of } \\
\text { Sphericity }\end{array}$} & $\begin{array}{l}\text { Approx. Chi- } \\
\text { Square }\end{array}$ & \\
\hline & & $\mathrm{df}$ & 10 & & & $\mathrm{df}$ & 15 \\
\hline & & Sig & 0.000 & & & Sig & 0.000 \\
\hline \multirow{4}{*}{$\begin{array}{l}\text { 3. Laboure } \\
\text { practices }\end{array}$} & \multicolumn{2}{|c|}{$\begin{array}{l}\text { Kaiser-Meyer-Olkin Measure of } \\
\text { Sampling Adequacy }\end{array}$} & 0.748 & \multirow{4}{*}{ 4. Environment } & \multicolumn{2}{|c|}{$\begin{array}{l}\text { Kaiser-Meyer-Olkin Measure of } \\
\text { Sampling Adequacy }\end{array}$} & 0.788 \\
\hline & \multirow{3}{*}{$\begin{array}{l}\text { Bartlett's Test of } \\
\text { Sphericity }\end{array}$} & $\begin{array}{l}\text { Approx. } \\
\text { Chi-Square }\end{array}$ & 382.206 & & \multirow{3}{*}{$\begin{array}{l}\text { Bartlett's Test of } \\
\text { Sphericity }\end{array}$} & $\begin{array}{l}\text { Approx. } \\
\text { Chi-Square }\end{array}$ & 252.155 \\
\hline & & $\mathrm{df}$ & 10 & & & $\mathrm{df}$ & 6 \\
\hline & & Sig & 0.000 & & & Sig & 0.000 \\
\hline \multirow{4}{*}{$\begin{array}{l}\text { 5. Fair operating } \\
\text { practices }\end{array}$} & \multicolumn{2}{|c|}{$\begin{array}{l}\text { Kaiser-Meyer-Olkin Measure of } \\
\text { Sampling Adequacy }\end{array}$} & 0.821 & \multirow{4}{*}{$\begin{array}{l}\text { 6. Consumer } \\
\text { issues }\end{array}$} & \multicolumn{2}{|c|}{$\begin{array}{l}\text { Kaiser-Meyer-Olkin Measure of } \\
\text { Sampling Adequacy. }\end{array}$} & 0.821 \\
\hline & \multirow{3}{*}{$\begin{array}{l}\text { Bartlett's Test of } \\
\text { Sphericity }\end{array}$} & $\begin{array}{c}\text { Approx. } \\
\text { Chi-Square }\end{array}$ & 306.184 & & \multirow{3}{*}{$\begin{array}{l}\text { Bartlett's Test of } \\
\text { Sphericity }\end{array}$} & $\begin{array}{c}\text { Approx. } \\
\text { Chi-Square }\end{array}$ & 239.939 \\
\hline & & $\mathrm{df}$ & 6 & & & $\mathrm{df}$ & 6 \\
\hline & & Sig & 0.000 & & & Sig & 0.000 \\
\hline \multirow{4}{*}{$\begin{array}{l}\text { 7. Community } \\
\text { involvement and } \\
\text { development }\end{array}$} & \multicolumn{2}{|c|}{$\begin{array}{c}\text { Kaiser-Meyer-Olkin Measure of } \\
\text { Sampling Adequacy }\end{array}$} & 0.840 & & & & \\
\hline & \multirow{3}{*}{$\begin{array}{l}\text { Bartlett's Test of } \\
\text { Sphericity }\end{array}$} & $\begin{array}{c}\text { Approx. } \\
\text { Chi-Square }\end{array}$ & 348.129 & & & & \\
\hline & & $\mathrm{df}$ & 10 & & & & \\
\hline & & Sig & 0.000 & & & & \\
\hline
\end{tabular}


Table 3. Factor loadings for the seven CSR dimensions [Source: Own survey result].

\begin{tabular}{|c|c|}
\hline Dimensions CSR & Factors \\
\hline 1. Organizational governance & Factor \\
\hline 0_1.1.1 The enterprise has a transparent process for making and communicating decisions & 0.76 \\
\hline $0 \_1.2$ The enterprise has a code of ethical conduct & 0.78 \\
\hline 0_1.3 The enterprise respects the regulations of national and international law & 0.83 \\
\hline 0_1.4 The enterprise is oriented to the needs of the stakeholders & 0.81 \\
\hline 0_1.5. Management plays an important role in motivating employees & 0.69 \\
\hline Eigenvalue & 3.00 \\
\hline$\%$ Var & $60.08 \%$ \\
\hline $\begin{array}{l}\text { H_2. } 1 \text { The company respects the personal rights and freedoms of employees to prevent discrimination } \\
\text { (cultural, racial, gender, religious, and age discrimination). }\end{array}$ & 0.86 \\
\hline H_2.2. the company respects the right to freedom of expression and freedom of association & 0.88 \\
\hline H_2.3. The company oversees and controls compliance with labor laws. & 0.87 \\
\hline H_2.4. The enterprise deals fairly and honestly analyses employee issues & 0.84 \\
\hline H_2.5. The company prevents abuses in the workplace (e.g., bullying, etc.) & 0.87 \\
\hline H_2.6. Enterprise does not work with organizations that do not respect/violate human rights & 0.68 \\
\hline Eigenvalue & 4.19 \\
\hline$\% \operatorname{Var}$ & $69.78 \%$ \\
\hline 3. Labor practices & Factor \\
\hline $\begin{array}{l}\text { L_3.1 The company shall ensure working conditions in accordance with applicable laws and regulations, } \\
\text { including maintaining health and safety standards. }\end{array}$ & 0.87 \\
\hline L_3.2. the company shall protect personal data of employees & 0.87 \\
\hline L_3.3 The company shall provide equal pay for work of the same value & 0.70 \\
\hline $\begin{array}{l}\text { L_3.4. The enterprise maintains human capital development and relationships e.g., through training courses } \\
\text { and team building events. }\end{array}$ & 0.68 \\
\hline L_3.5. Enterprise has a trade union & 0.81 \\
\hline Eigenvalue & 3.13 \\
\hline$\% \operatorname{Var}$ & $62.52 \%$ \\
\hline 4. Environment & Factor \\
\hline $\begin{array}{l}\text { E_4.1. The enterprise reduces negative impacts on the environment (e.g., efficient use of raw materials and } \\
\text { materials) }\end{array}$ & 0.87 \\
\hline E_4.2. Enterprise educates employees on pro-environmental behavior & 0.80 \\
\hline E_4.3. Enterprise reduces energy and water consumption & 0.87 \\
\hline E_4.4.4. Enterprise ensures that use of chemicals prohibited by law is eliminated & 0.78 \\
\hline Eigenvalue & 2.77 \\
\hline$\% \operatorname{Var}$ & $69.17 \%$ \\
\hline 5. Fair operating practices & Factor \\
\hline F_5.1. Employees care about the company's image by preventing corruption and embezzlement & 0.81 \\
\hline F_5.2 Employees care about company property & 0.90 \\
\hline F_5.3 Employees care to ensure the highest quality of service delivery & 0.89 \\
\hline F_5.4. The enterprise provides reliable information about services & 0.82 \\
\hline Eigenvalue & 2.94 \\
\hline$\% \operatorname{Var}$ & $73.45 \%$ \\
\hline 6. Consumer issues & Factor \\
\hline C_6.1. the company protects customers' personal information and ensures its security & 0.82 \\
\hline C_6.2 Enterprise provides accurate information about its sales policies & 0.85 \\
\hline C_6.3. Company handles complaints and disputes promptly & 0.85 \\
\hline $\begin{array}{l}\text { C_6.4. Company is oriented towards responsible consumption (education and awareness of customers } \\
\text { concerning rational use of water). }\end{array}$ & 0.81 \\
\hline
\end{tabular}


Table 3. Cont

\begin{tabular}{lcc}
\hline Dimensions CSR & Factors & 2.78 \\
\hline Eigenvalue & $69.37 \%$ \\
\hline \% Var & Factor & 0.76 \\
\hline 7. Community involvement and development & 0.66 \\
\hline CD_7.1 The company shall consult with the local community on investment and development & 0.81 \\
CD_7.2. the company is involved in the education of children and youth e.g., through workshops, & 0.90 \\
competitions & 0.87 \\
CD_7.3. the enterprise is committed to job creation e.g., through business diversification & 3.24 \\
the local community & $64.76 \%$ \\
CD_7.5. The enterprise undertakes initiatives for the development of the local community & \\
\hline Eigenvalue & \\
\hline$\%$ Var & \\
\hline
\end{tabular}

Therefore, it is important to improve their competences, e.g., by using modern management concepts such as participation, knowledge management, or organizational learning, in addition to developing interpersonal skills, which are essential in motivating employees effectively. The result is presented in the chart presented on the Figure 4. The second dimension of corporate social responsibility analyzed concerns human rights. In this dimension, the highest was sub-dimension $\mathrm{H} \_2.1$. , which assesses whether the company respects the rights and personal freedoms of its employees, in terms of counteracting discrimination (cultural, racial, gender, religious, age discrimination) (4.27), and sub-dimension $\mathrm{H} \_2.3$., concerning supervising and controlling the observance of labor law regulations (4.26). This situation indicates that the surveyed company conscientiously observes the implementation of legal norms, particularly those concerning the respect of the labor code, and the rights and personal freedoms of employees. Sub-dimension H_2.2. concerning the company's respect for the right to freedom of expression and freedom of association (4.1) was rated slightly lower, which indicates that, in the surveyed enterprise, employees can freely express their opinions and that there are trade unions within the organization. Subdimension H_2.4., which illustrates fair and honest consideration of employees' cases (3.94) and, at the same level sub-dimension H_2.5., which concerns counteracting abuses in the workplace (e.g., mobbing and others) (3.94), were rated slightly weaker in the organization. These results indicate that in the surveyed company, employees do not quite have a sense of justice and understanding by their superiors, and there few incidents of abuse of power.

The lowest rated sub-dimension was H_2.6., which assesses whether the company does not cooperate with organizations that do not respect/violate human rights (3.92). Unfortunately, in this case, employees were not fully aware of the organization's cooperation with different stakeholder groups. This situation indicates lower awareness of employees about the types and forms of cooperation with different entities. The results are presented in the chart presented on Figure 5.

Another analyzed dimension was labor practices. Among the sub-dimensions at the highest level, we note L_3.1., which concerns the company's provision of working conditions in accordance with the law, including maintaining standards of occupational health and safety (4.44). This result proves that the company pays significant attention to health and safety at work, which in turn contributes to the comfort of the subordinates. Equally highly rated was sub-dimension L_3.5., which concerns the functioning of trade unions in the company (4.42). Due to this approach, it is possible for employees to associate and build the social capital of the enterprise. Equally highly rated was sub-dimension. L_3.2., which focuses on the protection of employees' personal data (4.39). The high level of this subdimension indicates that the company makes every effort to ensure that legal regulations regarding personal data are respected. Weaker scores were given to sub-dimension L_3.4., which shows whether the enterprise cares about the development and relations of human 
capital, e.g., through training courses or integration meetings (3.66). This situation is not conducive to building social capital, the growth of which translates into greater efficiency and participation in achieving the organization's goals. Low social capital is not conducive to building bonds, social relations, commitment, or even trust. It is therefore important to build the managers' awareness in the area of social capital development as a valuable resource for each organization. Sub-dimension L_3.3., which concerns the provision of equal pay for work of equal value in the enterprise, was also rated lower (3.56). These results may indicate that the enterprise in its salary regulations has a spread of rates defined for a given position. This situation is quite unfavorable for employees because they feel treated unequally and, as a result, their motivation to work is affected. Therefore, it is important to unify the rates, which would provide a sense of equal treatment of employees working in parallel positions. The above results are presented in Figure 6.

Table 4. Descriptive statistics of dimensions and sub-dimensions of CSR [Source: Own survey result].

\begin{tabular}{|c|c|c|c|c|c|c|c|c|}
\hline Variable/Dimensions & Mean & Me & Min. & Max & $Q_{1}$ & $\mathrm{Q}_{3}$ & SD & CV \\
\hline 1. Organizational governance & 4.17 & 4.20 & 1.40 & 5.00 & 3.80 & 4.60 & 0.59 & 14.18 \\
\hline $\begin{array}{l}0 \_1.1 \text {. The enterprise has a transparent process for making and } \\
\text { communicating d }\end{array}$ & 3.89 & 4.00 & 2.00 & 5.00 & 3.00 & 4.00 & 0.83 & 21.45 \\
\hline 0_1.2. The enterprise has a code of ethical conduct & 4.61 & 5.00 & 1.00 & 5.00 & 4.00 & 5.00 & 0.63 & 13.61 \\
\hline $\begin{array}{l}0 \_1.3 \text {. The enterprise respects the regulations of national and } \\
\text { international law }\end{array}$ & 4.41 & 5.00 & 1.00 & 5.00 & 4.00 & 5.00 & 0.70 & 15.93 \\
\hline 0_1.4. The enterprise is oriented to the needs of the stakeholders & 4.03 & 4.00 & 1.00 & 5.00 & 4.00 & 5.00 & 0.78 & 19.25 \\
\hline $\begin{array}{l}\text { 0_1.5. Management plays an important role in } \\
\text { motivating employees }\end{array}$ & 3.90 & 4.00 & 1.00 & 5.00 & 3.00 & 4.00 & 0.88 & 22.66 \\
\hline 2. Human rights & 4.07 & 4.00 & 1.50 & 5.00 & 3.67 & 4.67 & 0.65 & 16.06 \\
\hline $\begin{array}{l}\text { H_2. } 1 \text { The company respects the personal rights and freedoms } \\
\text { of employees to prevent discrimination (cultural, racial, gender, } \\
\text { religious, and age discrimination). }\end{array}$ & 4.27 & 4.00 & 2.00 & 5.00 & 4.00 & 5.00 & 0.72 & 16.85 \\
\hline $\begin{array}{l}\text { H_2.2. the company respects the right to freedom of expression } \\
\text { and freedom of association }\end{array}$ & 4.10 & 4.00 & 2.00 & 5.00 & 4.00 & 5.00 & 0.73 & 17.81 \\
\hline $\begin{array}{l}\text { H_2.3. The company oversees and controls compliance with } \\
\text { labor laws. }\end{array}$ & 4.26 & 4.00 & 1.00 & 5.00 & 4.00 & 5.00 & 0.71 & 16.60 \\
\hline $\begin{array}{l}\text { H_2.4. The enterprise deals fairly and honestly analyses } \\
\text { employee issues }\end{array}$ & 3.94 & 4.00 & 2.00 & 5.00 & 3.00 & 5.00 & 0.84 & 21.29 \\
\hline $\begin{array}{l}\text { H_2.5. The company prevents abuses in the workplace (e.g., } \\
\text { bullying, etc.) }\end{array}$ & 3.94 & 4.00 & 1.00 & 5.00 & 4.00 & 5.00 & 0.86 & 21.91 \\
\hline $\begin{array}{l}\text { H_2.6. Enterprise does not work with organizations that do not } \\
\text { respect/violate human rights }\end{array}$ & 3.92 & 4.00 & 1.00 & 5.00 & 3.00 & 5.00 & 0.86 & 21.88 \\
\hline 3. Labor practices & 4.10 & 4.00 & 1.40 & 5.00 & 3.80 & 4.60 & 0.63 & 15.46 \\
\hline $\begin{array}{l}\text { L_3.1 The company shall ensure working conditions in } \\
\text { accordance with applicable laws and regulations, including } \\
\text { maintaining health and safety standards. }\end{array}$ & 4.44 & 4.00 & 1.00 & 5.00 & 4.00 & 5.00 & 0.64 & 14.50 \\
\hline L_3.2. the company shall protect personal data of employees & 4.39 & 4.00 & 1.00 & 5.00 & 4.00 & 5.00 & 0.72 & 16.38 \\
\hline $\begin{array}{l}\text { L_3.3 The company shall provide equal pay for work of the } \\
\text { same value }\end{array}$ & 3.56 & 4.00 & 1.00 & 5.00 & 3.00 & 4.00 & 0.99 & 27.88 \\
\hline $\begin{array}{l}\text { L_3.4. The enterprise maintains human capital development } \\
\text { and relationships e.g., through training courses and team } \\
\text { building events. }\end{array}$ & 3.66 & 4.00 & 1.00 & 5.00 & 3.00 & 4.00 & 1.06 & 29.00 \\
\hline L_3.5. Enterprise has a trade union & 4.43 & 4.00 & 2.00 & 5.00 & 4.00 & 5.00 & 0.63 & 14.27 \\
\hline 4. Environment & 3.94 & 4.00 & 1.50 & 5.00 & 3.50 & 4.50 & 0.64 & 16.33 \\
\hline $\begin{array}{l}\text { E_4.1. The enterprise reduces negative impacts on the } \\
\text { environment (e.g., efficient use of raw materials and materials) }\end{array}$ & 4.08 & 4.00 & 2.00 & 5.00 & 4.00 & 5.00 & 0.75 & 18.37 \\
\hline $\begin{array}{l}\text { E_4.2. Enterprise educates employees on pro-environmental } \\
\text { behavior }\end{array}$ & 3.45 & 4.00 & 1.00 & 5.00 & 3.00 & 4.00 & 0.93 & 26.90 \\
\hline E_4.3. Enterprise reduces energy and water consumption & 3.94 & 4.00 & 1.00 & 5.00 & 4.00 & 4.00 & 0.75 & 19.08 \\
\hline $\begin{array}{l}\text { E_4.4.4. Enterprise ensures that use of chemicals prohibited by } \\
\text { law is eliminated }\end{array}$ & 4.30 & 4.00 & 1.00 & 5.00 & 4.00 & 5.00 & 0.67 & 15.55 \\
\hline
\end{tabular}


Table 4. Cont.

\begin{tabular}{|c|c|c|c|c|c|c|c|c|}
\hline $\begin{array}{l}\text { Variable/Dimensions } \\
\text { 5. Fair operating practices }\end{array}$ & $\begin{array}{l}\text { Mean } \\
4.15\end{array}$ & $\begin{array}{l}\text { Me } \\
4.00\end{array}$ & $\begin{array}{l}\text { Min. } \\
2.00\end{array}$ & $\begin{array}{l}\text { Max } \\
5.00\end{array}$ & $\begin{array}{c}\mathrm{Q}_{1} \\
3.75\end{array}$ & $\begin{array}{c}\mathrm{Q}_{3} \\
4.50\end{array}$ & $\begin{array}{l}\text { SD } \\
0.61\end{array}$ & $\begin{array}{c}\text { CV } \\
14.63\end{array}$ \\
\hline $\begin{array}{l}\text { F_5.1. Employees care about the company's image by } \\
\text { preventing corruption and embezzlement }\end{array}$ & 3.98 & 4.00 & 2.00 & 5.00 & 4.00 & 4.00 & 0.76 & 19.07 \\
\hline F_5.2 Employees care about company property & 4.14 & 4.00 & 2.00 & 5.00 & 4.00 & 5.00 & 0.71 & 17.06 \\
\hline $\begin{array}{l}\text { F_5.3 Employees care to ensure the highest quality of service } \\
\text { delivery }\end{array}$ & 4.28 & 4.00 & 2.00 & 5.00 & 4.00 & 5.00 & 0.69 & 16.21 \\
\hline $\begin{array}{l}\text { F_5.4. The enterprise provides reliable information } \\
\text { about services }\end{array}$ & 4.19 & 4.00 & 2.00 & 5.00 & 4.00 & 5.00 & 0.68 & 16.17 \\
\hline 6. Consumer issues & 4.16 & 4.00 & 1.50 & 5.00 & 3.75 & 4.75 & 0.62 & 14.93 \\
\hline $\begin{array}{l}\text { C_6.1. the company protects customers' personal information } \\
\text { and ensures its security }\end{array}$ & 4.39 & 4.00 & 1.00 & 5.00 & 4.00 & 5.00 & 0.66 & 15.01 \\
\hline $\begin{array}{l}\text { C_6.2 Enterprise provides accurate information about its sales } \\
\text { policies }\end{array}$ & 4.13 & 4.00 & 1.00 & 5.00 & 4.00 & 5.00 & 0.75 & 18.10 \\
\hline C_6.3. Company handles complaints and disputes promptly & 4.11 & 4.00 & 2.00 & 5.00 & 4.00 & 5.00 & 0.75 & 18.16 \\
\hline $\begin{array}{l}\text { C_6.4. Company is oriented towards responsible consumption } \\
\text { (education and awareness of customers concerning rational use } \\
\text { of water). }\end{array}$ & 3.99 & 4.00 & 2.00 & 5.00 & 4.00 & 5.00 & 0.82 & 20.69 \\
\hline 7. Community involvement and development & 3.58 & 3.60 & 1.20 & 5.00 & 3.20 & 4.00 & 0.68 & 18.92 \\
\hline $\begin{array}{l}\text { CD_7.1 The company shall consult with the local community } \\
\text { on investment and development }\end{array}$ & 3.68 & 4.00 & 1.00 & 5.00 & 3.00 & 4.00 & 0.84 & 22.87 \\
\hline $\begin{array}{l}\text { CD_7.2. the company is involved in the education of children } \\
\text { and youth e.g., through workshops, competitions }\end{array}$ & 4.03 & 4.00 & 1.00 & 5.00 & 4.00 & 4.00 & 0.76 & 18.95 \\
\hline $\begin{array}{l}\text { CD_7.3. the enterprise is committed to job creation e.g., } \\
\text { through business diversification }\end{array}$ & 3.37 & 3.00 & 1.00 & 5.00 & 3.00 & 4.00 & 0.86 & 25.45 \\
\hline $\begin{array}{l}\text { CD_7.4. the enterprise participates in creating innovations to } \\
\text { help solve environmental and social problems in the } \\
\text { local community }\end{array}$ & 3.41 & 3.00 & 1.00 & 5.00 & 3.00 & 4.00 & 0.87 & 25.54 \\
\hline $\begin{array}{l}\text { CD_7.5. The enterprise undertakes initiatives for the } \\
\text { development of the local community }\end{array}$ & 3.43 & 3.00 & 1.00 & 5.00 & 3.00 & 4.00 & 0.88 & 25.67 \\
\hline CSR & 4.02 & 4.00 & 1.61 & 5.00 & 3.67 & 4.39 & 0.54 & 13.41 \\
\hline
\end{tabular}

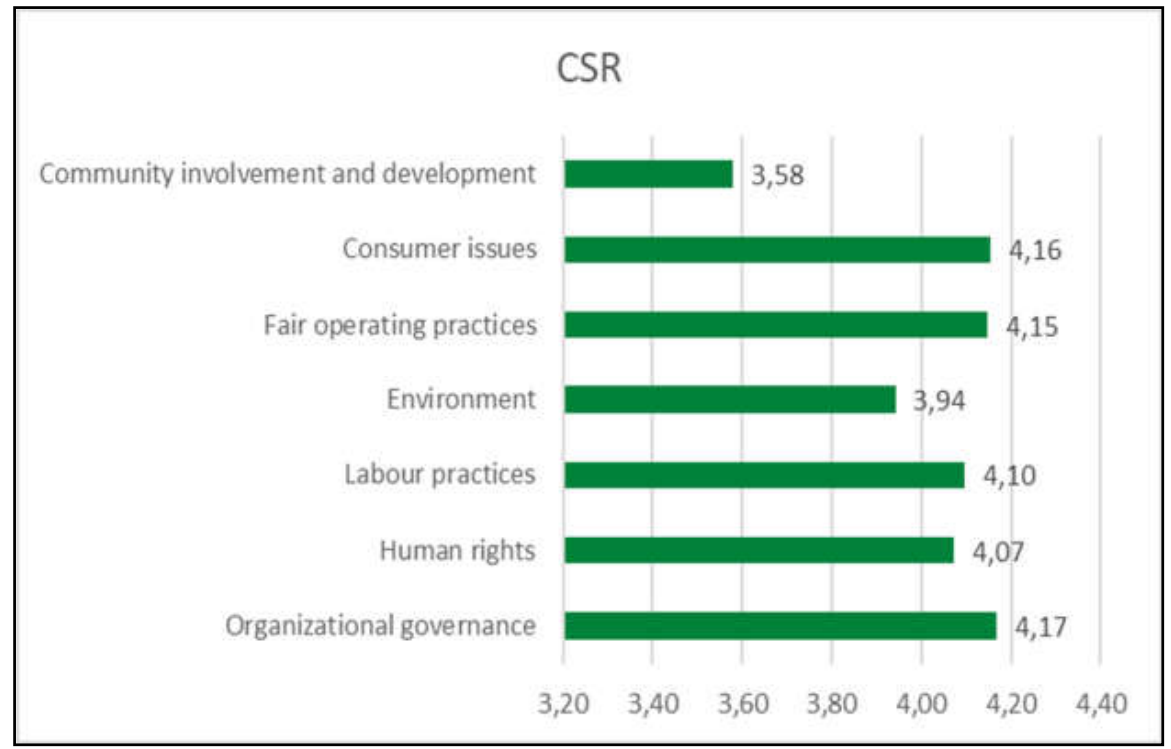

Figure 3. Level of corporate social responsibility (CSR) [Source: Own survey result]. 


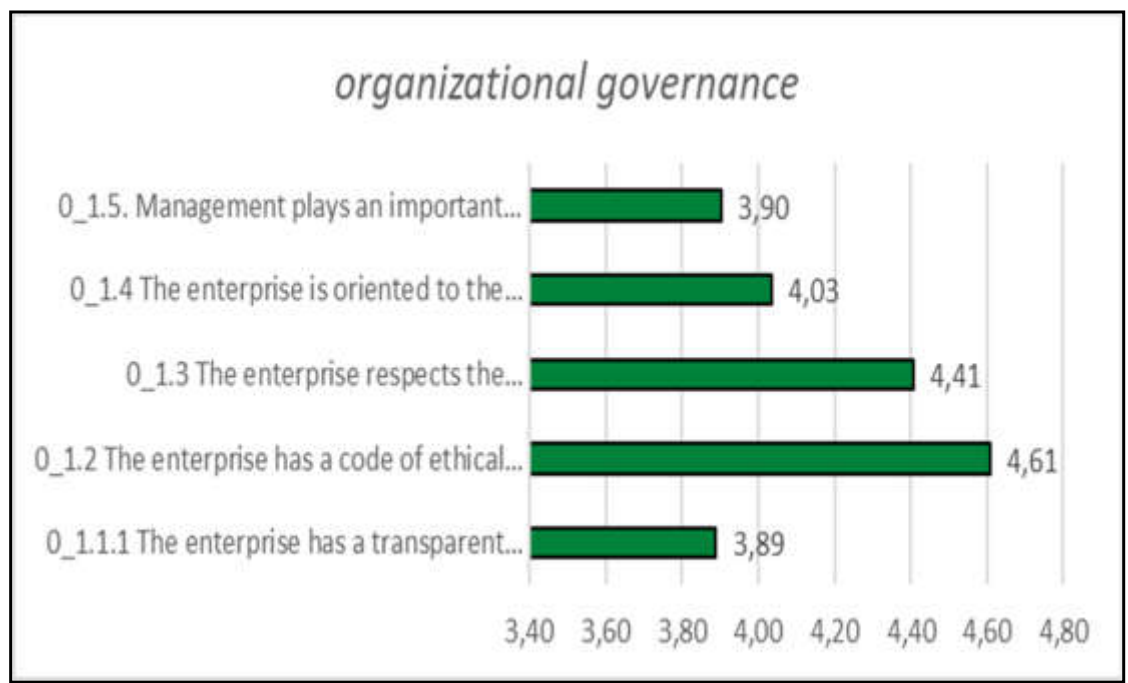

Figure 4. Organization governance [Source: Own survey result].

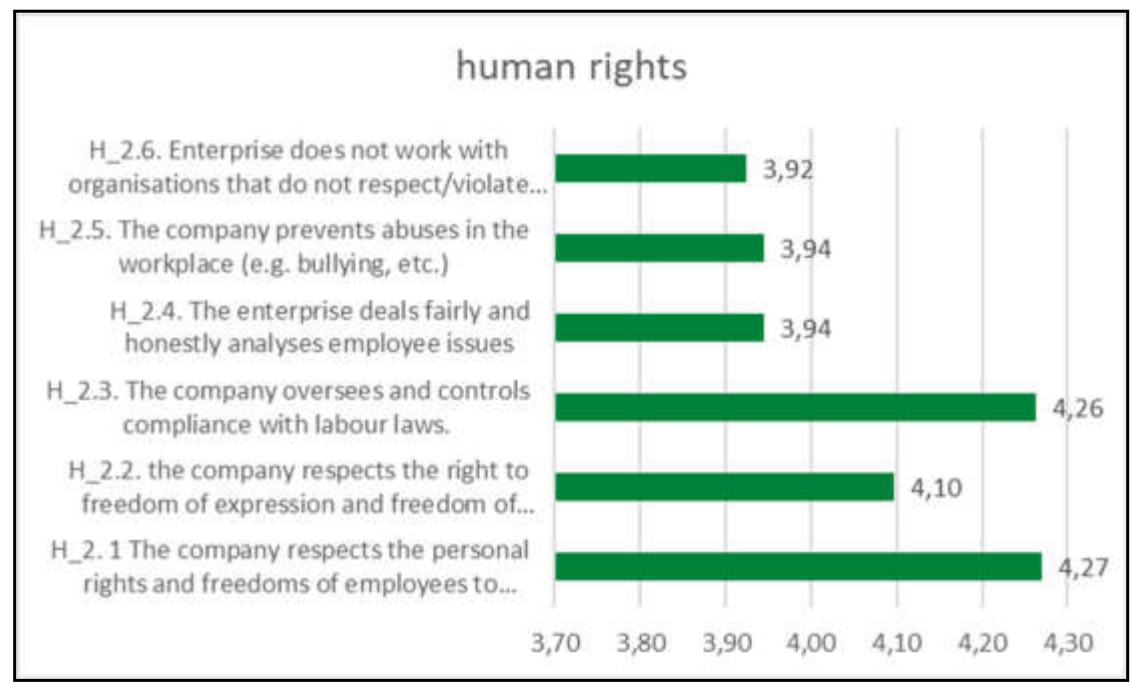

Figure 5. Human rights [Source: Own survey result].

The fourth dimension analyzed is the environment. The highest scores were given to sub-dimension E_4.4. concerning the company's efforts to eliminate the use of chemical substances banned by law (4.30) and E_4.1. indicating the company's limitation of negative impact on the environment (4.08). This approach is highly important, particularly as it relates to compliance with legal regulations, or effective use of raw materials and materials, which ultimately contributes to both environmental protection and the economy of the organization. A slightly lower rating was given to sub-dimension E_4.3. concerning the company's reduction of energy and water consumption (3.94). It is important for the company to pay attention to this form of saving, which could constitute a significant income for the whole company. The lowest score was given to sub-dimension E_4.2. concerning education of employees in pro-environmental behavior (3.45). This is the weaker side of the enterprise, which may affect the morale of employees and their degree of involvement in activities to improve environmental quality. Therefore, it is important for the company to introduce an environmental policy that is oriented towards a more economical use of resources and to promote activities aimed at protecting the environment. The results are presented in the chart shown in Figure 7. 


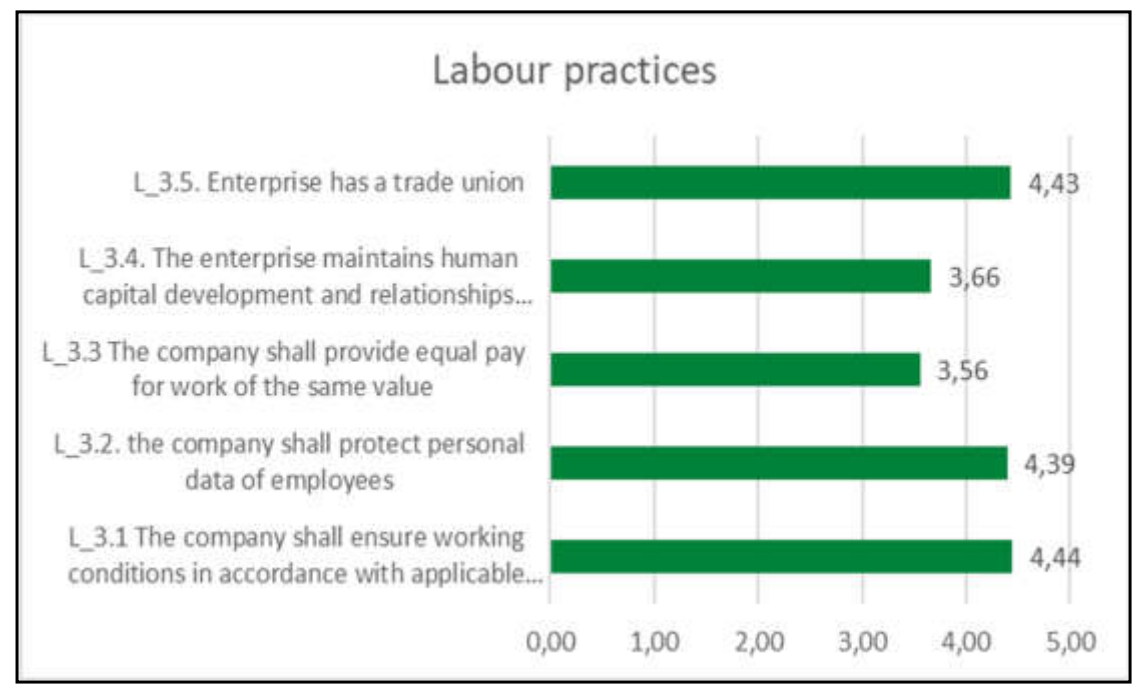

Figure 6. Labor practices [Source: Own survey result].

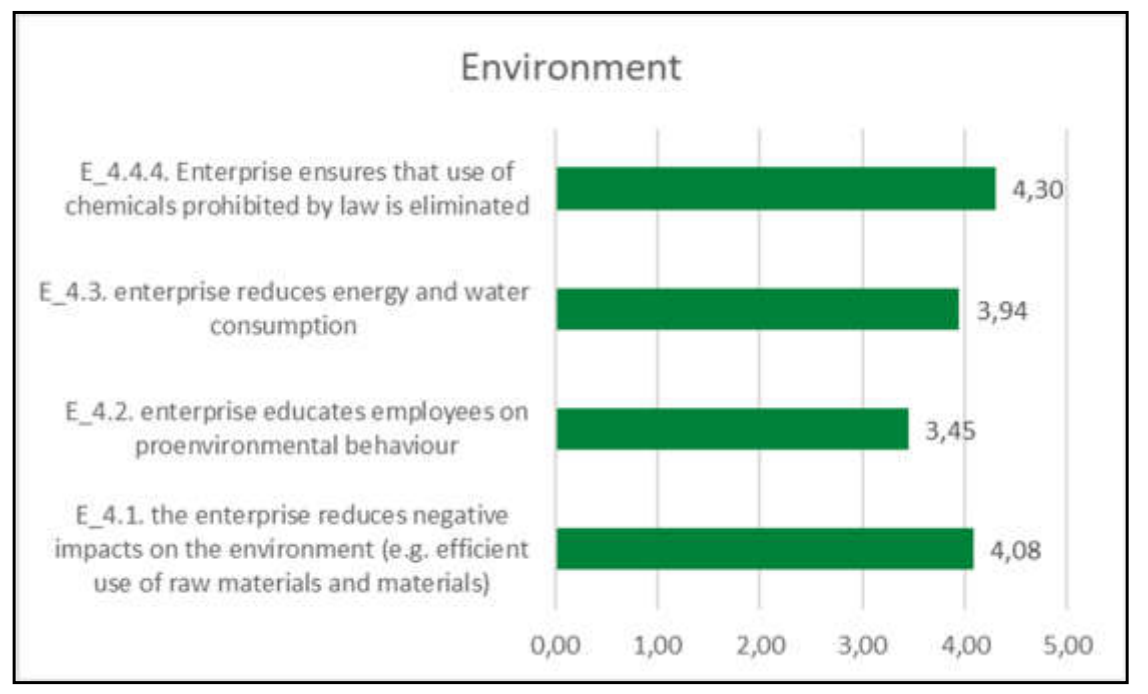

Figure 7. Environment [Source: Own survey result].

Another dimension analyzed was fair operating practices. This dimension is at a relatively high level in the organization. The highest score was given to sub-dimension F_5.3., which refers to employees taking care to ensure the highest quality of service delivery (4.28) and sub-dimension F_5.4., which indicates that the company provides reliable information about its services (4.19), in addition to sub-dimension F_5.2., which focuses on actions by the company's employees to take care of the company's property (4.14). These results indicate that employees are strongly committed to providing high quality services and reliable information about them; moreover, they care about the organization in which they work through, among other things, effective market service or customer satisfaction, in addition to its economic efficiency. Sub-dimension F_5.1., which assesses whether employees care about the company's image by preventing corruption and embezzlement, was scored slightly lower (3.98).

This situation indicates that there may still be incidental situations relating to corruption in state organizations. It is therefore important to prevent such situations, for example, by educating employees in this respect. The results are presented in Figure 8. 


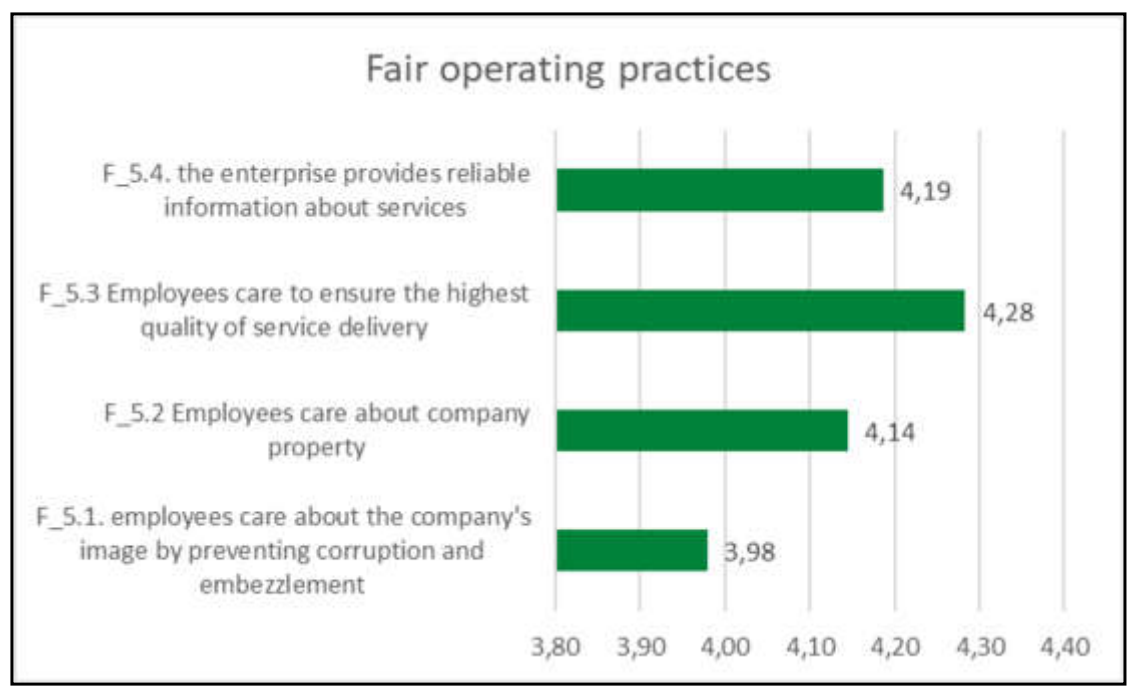

Figure 8. Fair operating practices [Source: Own survey result].

Another dimension analyzed was consumer issues. Sub-dimension C_6.1., which concerns the company's care for customers' personal data protection and security (4.39) was ranked highest, followed by sub-dimension C_6.2. indicating that the company provides reliable information on its sales policies (4.13), and sub-dimension C_6.3. regarding efficient handling of complaints and disputes (4.11).

This situation indicates that the enterprise pays significant attention to the protection of classified data not only of its employees, but also of its stakeholders. In addition, information about the services provided and their sales are transparent, and any inaccuracies or disputes are dealt with and resolved very quickly. Slightly weaker is sub-dimension C_6.4., which assesses the extent to which the company is oriented towards responsible consumption (3.99). This dimension refers to education and raising customers' awareness in the field of rational water management.

Here, it is advisable for the company to be more oriented towards developing stakeholder knowledge in the area of water management. It can do this during meetings with the local community, education in schools, or local events. The results are presented in Figure 9.

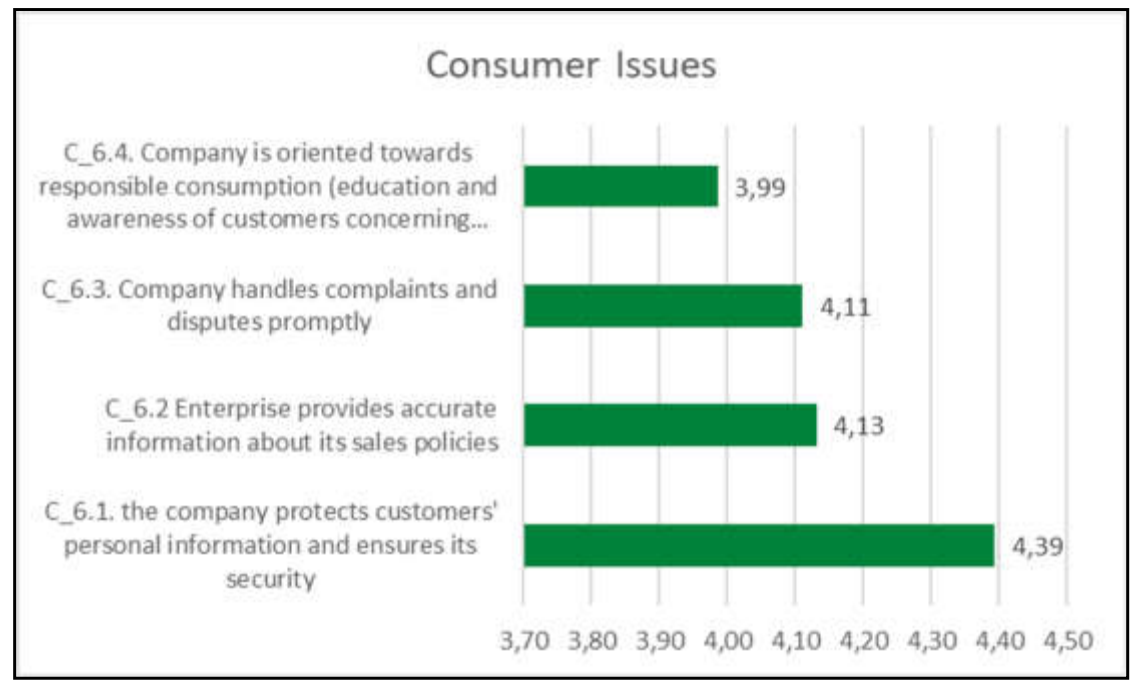

Figure 9. Consumer issues [Source: Own survey result].

The last dimension analyzed was community involvement and development (Figure 10). Overall, this dimension was rated slightly lower than the other dimensions. The sub- 
dimension with a relatively high level compared to the others is CD_7.2., which concerns the company's involvement in the education of children and youth (4.03). This shows that the company is interested in building relations with a specific group of the local community-youth. It does this through workshops and competitions in schools, which is its strong point. Among the sub-dimensions that form its weaker points, we note: CD_7.1. assessing the extent to which the enterprise consults with the local community on investment and development (3.68), sub-dimension CD_7.5. regarding the enterprise's initiative to develop the local community (3.43), CD_7.4. assessing participation in the creation of innovations to help solve environmental and social problems in the local community (3.41), and sub-dimension CD_7.3. regarding the enterprise's involvement in the creation of new jobs (3.37). This may indicate that the company is not entirely interested in diversifying its activities and creating new jobs, which in the long run may affect its development.

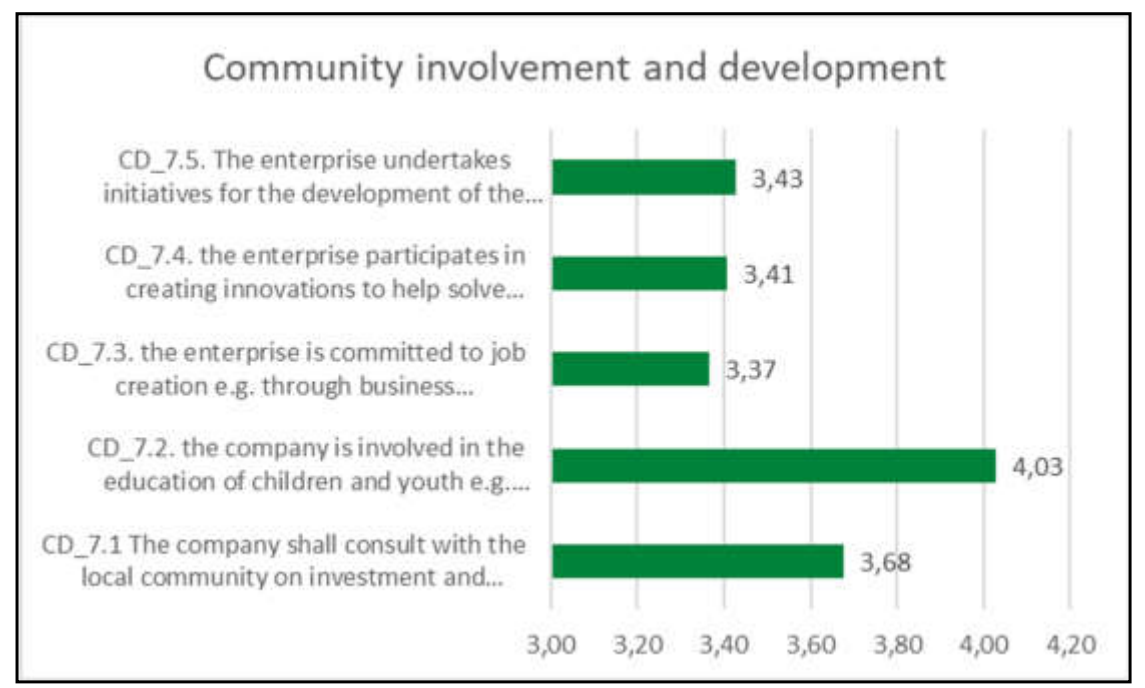

Figure 10. Community involvement and development [Source: Own survey result].

Additionally, as the research indicates, the company consults with the local community in investment or development issues to a small extent. It also shows insufficient initiative in implementing innovative solutions that help solve environmental or social problems in a given area. It is therefore important to increase the company's orientation on building ties with the local community, which will result in many positive effects.

To summarize, the presented data show that the average level of the synthetic CSR indicator is relatively high at 4.02. Individual values concerning CSR dimensions are thus at a relatively high level. The highest average level is 4.17 (organizational governance dimension), whereas the lowest is 3.58 (community involvement and development dimension). This situation indicates that the surveyed company is focused on activities in the field of CSR, whereas the awareness of employees is at a relatively high level.

Figure 11 shows the result of testing the hypothesis of normality of the CSR distribution using the chi square test. The histogram plot of CSR provide a fast and reliable way to visualize the distribution of a data sample.

The analysis of the CSR variable distribution shows that $87.6 \%$ of the respondents rated the level of the analyzed variable at more than 3.5 , and almost half at more than 4. Only $3 \%$ of the respondents rated the CSR variable lower than 3. Hypothesis H1 was thus confirmed.

Hypotheses 2 (H2). There are statistically significant differences between different dimension of CSR.

To verify Hypothesis $2(\mathrm{H} 2)$, which assumes that there are statistically significant differences between individual CSR dimensions in the opinion of employees and man- 
agers, a non-parametric alternative one-way analysis of variance was conducted using the Kruskal-Wallis test. The Kruskal-Wallis test was used because the assumptions of classical analysis ANOVA were not met (not all distributions of the analyzed variables were normal). Graphically, the test result is shown in Figure 12.

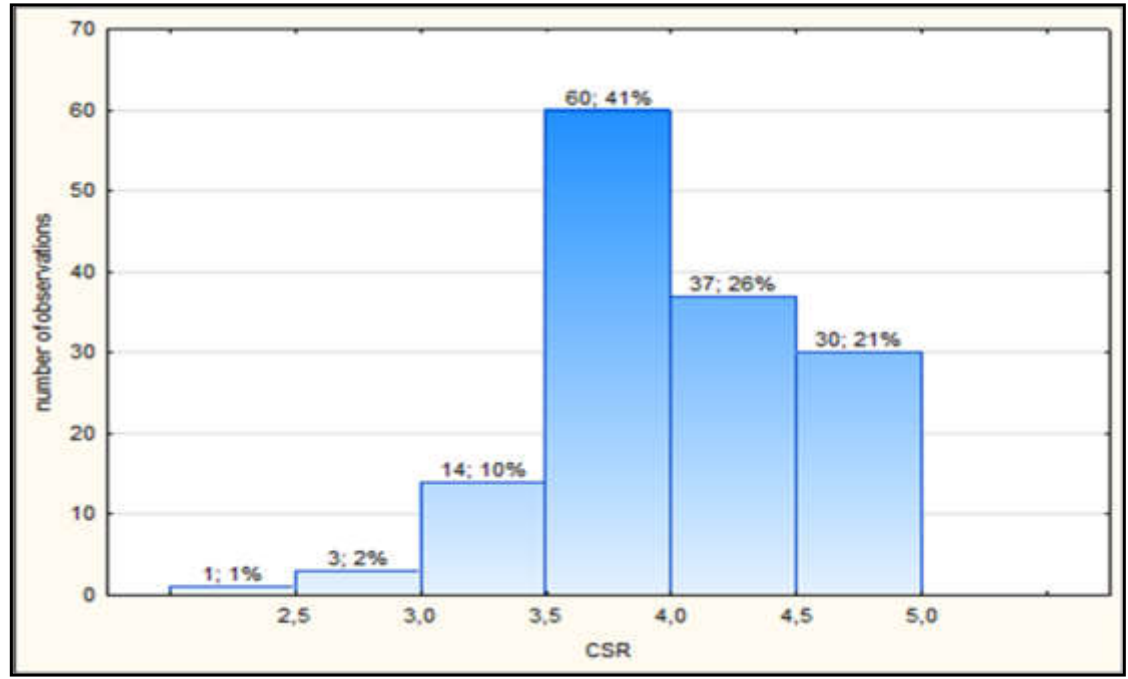

Figure 11. Histogram of the variable CSR [Source: Own survey result].

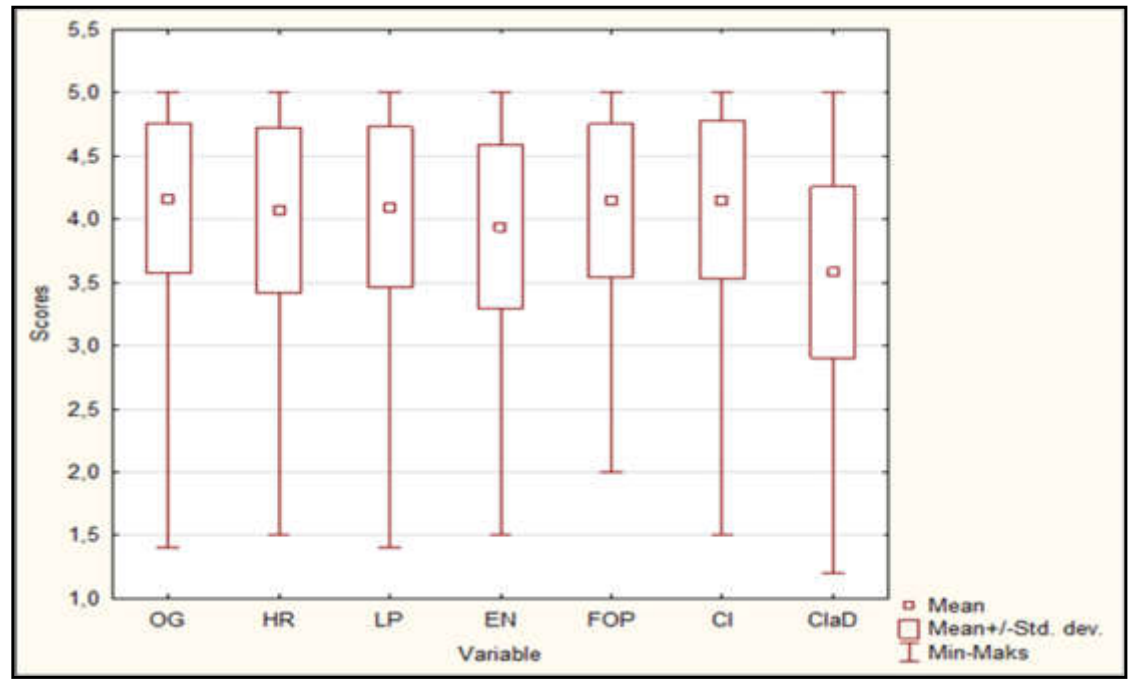

Figure 12. Graphical interpretation of the Kruskal-Wallis test results for H1 [Source: Own survey result].

The result of the Kruskal-Wallis test showed that there was a statistically significant difference in score between the different dimensions of CSR, the value of Kruskal-Wallis test $\mathrm{H}(6, \mathrm{~N}=1015)=89.73871$ and $p=0.0000$. To determine which dimensions are different from others, post-hoc testing can be conducted.

The $p$-values of the probabilities for multiple comparisons allowed the following conclusion to be made: ratings of the dimension of social engagement are significantly lower than ratings of the other dimensions. However, the scores for the other six dimensions do not differ significantly.

In summary, the results presented in Figure 12 confirm the $\mathrm{H} 2$ hypothesis, indicating statistically significant differences between individual dimensions of CSR.

Hypotheses 3 (H3). There are statistically significant differences in the evaluation of the level of CSR by managers and employees. 
The following table presents descriptive statistics of the CSR dimensions as perceived by managers and employees.

As can be seen from Table 5, taking into account the assessment of individual dimensions of CSR by the managers and employees of the surveyed enterprise, there are no significant differences in the assessment of individual dimensions. Both the managers and employees rated the level of CSR similarly in each of the seven dimensions. However, the managers rated organizational governance highest (4.23), whereas the employees rated fair operating practices highest (4.20). At this point, it is worth emphasizing the significant role of the managerial staff in shaping the awareness of employees, and their appropriate attitudes and behaviours, in addition to increasing their knowledge, e.g., in the area of CSR. The above hypothesis was not confirmed.

Table 5. Descriptive statistics of dimensions of CSR [Source: Own survey result].

\begin{tabular}{|c|c|c|c|c|c|c|c|c|}
\hline Dimensions/Position & Mean & $\mathrm{Me}$ & Min. & Max. & $\mathbf{Q}_{1}$ & $\mathbf{Q}_{3}$ & SD & $\mathrm{CV}$ \\
\hline \multicolumn{9}{|c|}{ 1. Organizational governance } \\
\hline managers & 4.23 & 4.20 & 1.40 & 5.00 & 4.00 & 4.60 & 0.59 & 13.92 \\
\hline employees & 4.14 & 4.20 & 2.80 & 5.00 & 3.80 & 4.60 & 0.59 & 14.32 \\
\hline \multicolumn{9}{|l|}{ 2. Human rights } \\
\hline managers & 4.07 & 4.00 & 1.50 & 5.00 & 3.83 & 4.50 & 0.68 & 16.73 \\
\hline employees & 4.08 & 4.00 & 2.50 & 5.00 & 3.50 & 4.67 & 0.65 & 15.83 \\
\hline \multicolumn{9}{|l|}{ 3. Laboure practices } \\
\hline managers & 4.11 & 4.00 & 1.40 & 5.00 & 3.80 & 4.60 & 0.65 & 15.80 \\
\hline employees & 4.09 & 4.00 & 2.60 & 5.00 & 3.60 & 4.60 & 0.63 & 15.38 \\
\hline \multicolumn{9}{|l|}{ 4. Environment } \\
\hline managers & 4.06 & 4.00 & 1.50 & 5.00 & 3.75 & 4.50 & 0.64 & 15.64 \\
\hline employees & 3.89 & 4.00 & 1.75 & 5.00 & 3.50 & 4.25 & 0.64 & 16.56 \\
\hline \multicolumn{9}{|c|}{ 5. Fair operating practices } \\
\hline managers & 4.04 & 4.00 & 2.00 & 5.00 & 3.75 & 4.25 & 0.62 & 15.22 \\
\hline employees & 4.20 & 4.25 & 2.00 & 5.00 & 4.00 & 4.75 & 0.60 & 14.30 \\
\hline \multicolumn{9}{|l|}{ 6. Consumer issues } \\
\hline managers & 4.09 & 4.00 & 1.50 & 5.00 & 3.75 & 4.25 & 0.64 & 15.59 \\
\hline employees & 4.19 & 4.00 & 2.50 & 5.00 & 3.75 & 4.75 & 0.61 & 14.63 \\
\hline \multicolumn{9}{|c|}{ 7. Community involvement and development } \\
\hline managers & 3.60 & 3.60 & 1.20 & 5.00 & 3.20 & 4.00 & 0.76 & 21.25 \\
\hline employees & 3.57 & 3.40 & 1.60 & 5.00 & 3.20 & 4.00 & 0.64 & 17.83 \\
\hline \multicolumn{9}{|l|}{ CSR } \\
\hline managerial staff & 4.03 & 4.00 & 1.61 & 5.00 & 3.82 & 4.36 & 0.57 & 14.07 \\
\hline employees & 4.02 & 4.00 & 2.70 & 5.00 & 3.61 & 4.45 & 0.53 & 13.17 \\
\hline
\end{tabular}

Hypotheses 4 (H4). A control variable such as working experience affects the level of perception of employees and managers of a company with respect to CSR.

The Kruskal-Wallis test was used to verify Hypothesis H4. Graphically, the test result is shown in Figure 13.

The result of the Kruskal-Wallis test showed that there are no significant statistical differences in the perception levels of groups of employees and managers of the company with different levels of seniority in relation to CSR (Kruskal-Wallis test statistic $\mathrm{H}$ $(4, N=145)=4.044597 p=0.4000)$. Thus, the hypothesis that the control variable of working experience affects the level of perception of employees and managers of a company with respect to CSR was not confirmed. 


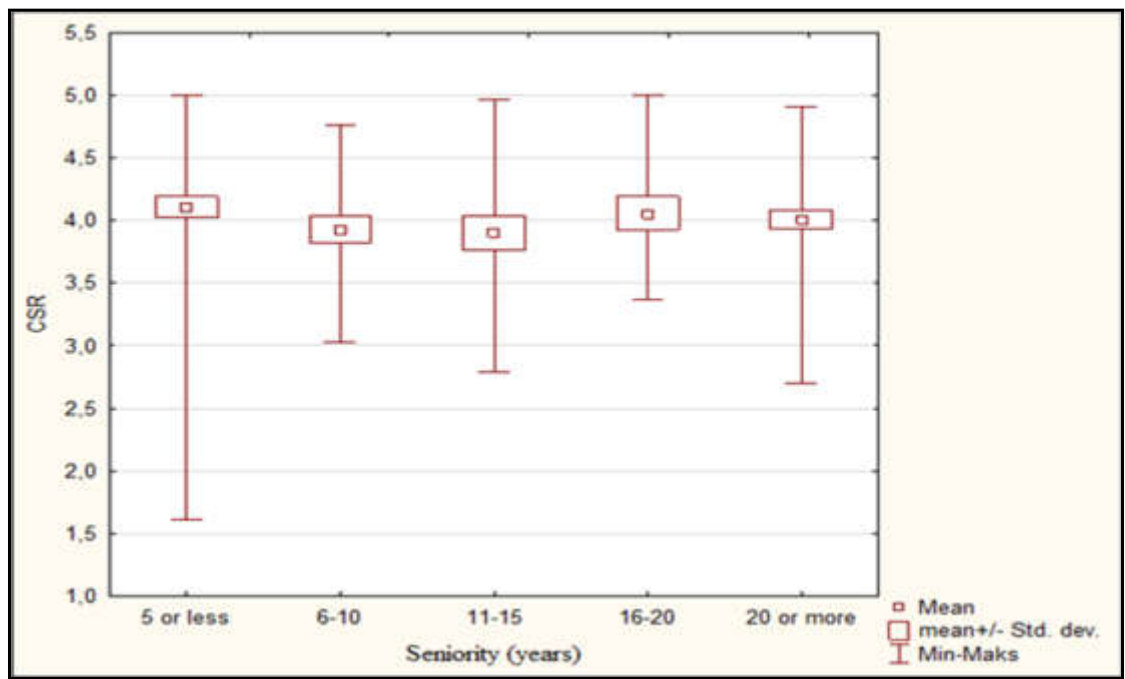

Figure 13. Graphical interpretation of the Kruskal-Wallis test results for H4 [Source: Own survey result].

\section{Discussion}

The conducted research contributes to the knowledge of how CSR practices are shaped in water companies, and how they are perceived by employees and managers of these companies. The obtained results fill the identified cognitive and research gap. This is associated, inter alia, with the adopted research method based on the case study method. The presented research has some limitations resulting from the development of the CSR concept, in addition to methodological aspects. Widening and deepening the research based on the use of quantitative methods on a larger sample of examined water supply enterprises would allow more generalized conclusions to be formulated.

The main objective of the study and the specific objectives were achieved through theoretical considerations and empirical research.

As a result of the conducted research, the formulated research hypotheses were verified. A summary of the hypotheses is included in Table 6.

Table 6. The summary of hypotheses. [Source: Own survey result].

\begin{tabular}{clc}
\hline Hypothesis & \multicolumn{1}{c}{ Hypothesis Content } & Results \\
\hline H1 & $\begin{array}{l}\text { Corporate Social Responsibility of the company is at a high } \\
\text { level in the opinion of employees and managers } \\
\text { There are statistically significant differences between different } \\
\text { dimension of CSR }\end{array}$ & confirmed \\
H3 & $\begin{array}{l}\text { There are statistically significant differences in the evaluation of } \\
\text { the level of CSR by managers and employees } \\
\text { A control variable such as working experience affects the level } \\
\text { of perception of employees and managers of a company with } \\
\text { respect to CSR }\end{array}$ & falsified \\
\hline
\end{tabular}

The results of the study and the identified limitations set directions for future research focusing on the research questions formulated below. Regarding these questions, it would be of interest to compare corporate social responsibility between other enterprises in Poland and the Czech Republic. In particular, it would be of interest to answer the following conceptual questions, which emerged during the literature and empirical research:

1. How is corporate social responsibility shaped in water and wastewater companies in other countries?

2. How can corporate social responsibility be shaped in a more effective way?

3. In organizations in which modern management concepts are applied, is the level of CSR higher than in organizations that do not use such concepts? 
4. What external and internal factors most significantly affect the possibility of developing corporate social responsibility?

5. Is there a relationship between the level of development of the CSR concept and its dimensions and organizational effectiveness, including financial results achieved by the company?

Another area of interest appears to be the study of the relationship between the level of CSR and the level of energy management or environmental awareness of company employees. Answering the above questions is not likely to be easy, but would allow the observation of numerous phenomena that would contribute to more effective management of organizations, and may be the subject of interest in the area of social responsibility in the future.

\section{Conclusions}

Application of the CSR concept has an impact on the realization of the idea of sustainable development, while taking into account the expectations of various stakeholder groups, thus contributing to higher employee satisfaction, as well as shaping a positive corporate image.

The collected research material allowed the following cognitive and practical conclusions to be formulated:

1. The literature research carried out in the field of corporate social responsibility indicated the topicality of the issue and the existing demand for empirical research in this area.

2. Corporate social responsibility is a multidimensional and interdisciplinary concept. Important dimensions of corporate social responsibility include: organizational governance, human rights, labor practices, environment, fair operating practices, consumer issues, social commitment, and community development.

3. Executives can contribute to the level of corporate social responsibility in water and wastewater companies by impacting all dimensions of CSR.

4. The research results indicated the dimension concerning the environment and activities for the development of pro-environmental attitudes of employees was particularly low. Thus, it is important to pay special attention to the definition of the organization's pro-environmental policy, and to ensure the promotion of activities aimed at appropriate protection of the environment and surface waters.

5. Improving the level of corporate social responsibility can be undertaken in the process of formation using modern management concepts: organizational culture, organizational learning and knowledge management, participation, and benchmarking. It is expected that this would result in an increase in value.

Most of the conclusions presented in the paper have practical applications. The theoretically developed and empirically verified research model can be used in water and sanitization enterprises in both the Czech Republic and other countries. Additionally, this work provides managers in water and sewage enterprises with a specific tool to identify corporate social responsibility based on ISO 26000. The conducted research is a precursor to further extended research on the concept of corporate social responsibility in water supply enterprises.

Author Contributions: The following statements should be used Conceptualization E.P., J.M.-S. and I.K.-B.; methodology, J.M.-S. and E.P.; software, R.G. and M.G.; resources, J.M.-S., E.P., M.G., R.G. and I.K.-B.; writing — original draft preparation, E.P. an J.M.-S.; writing—review and editing, I.K.-B.; visualization, E.P. and I.K.-B.; supervision, J.M.-S. All authors have read and agreed to the published version of the manuscript.

Funding: There was no external funding.

Institutional Review Board Statement: Not applicable.

Informed Consent Statement: Not applicable. 
Data Availability Statement: Not applicable.

Conflicts of Interest: The authors declare no conflict of interest.

\section{References}

1. Agyemang, O.S.; Ansong, A. Corporate social responsibility and firm performance of Ghanaian SMEs. J. Glob. Responsib. 2017, 8. [CrossRef]

2. Hale, J.; Long, S. A Time Series Sustainability Assessment of a Partial Energy Portfolio Transition. Energies 2020, 14, 141. [CrossRef]

3. Gajdzik, B.; Grabowska, S.; Saniuk, S.; Wieczorek, T. Sustainable Development and Industry 4.0: A Bibliometric Analysis Identifying Key Scientific Problems of the Sustainable Industry 4.0. Energies 2020, 13, 4254. [CrossRef]

4. Stawiarska, E.; Sobczak, P. The Impact of Intelligent Transportation System Implementations on the Sustainable Growth of Passenger Transport in EU Regions. Sustainability 2018, 10, 1318. [CrossRef]

5. Branco, M.C.; Rodrigues, L.L. Corporate Social Responsibility and Resource-Based Perspectives. J. Bus. Ethics 2006, 69. [CrossRef]

6. Machnik-Słomka, J. Smart specialization as a factor stimulating innovative development of water and wastewater economy. E3S Web Conf. 2018, 59. [CrossRef]

7. Chang, R.-D.; Zuo, J.; Zhao, Z.-Y.; Zillante, G.; Gan, X.-L.; Soebarto, V. Evolving theories of sustainability and firms: History, future directions and implications for renewable energy research. Renew. Sustain. Energy Rev. 2017, 72. [CrossRef]

8. Abbas, J.; Mahmood, S.; Ali, H.; Raza, M.A.; Ali, G.; Aman, J.; Bano, S.; Nurunnabi, M. The Effects of Corporate Social Responsibility Practices and Environmental Factors through a Moderating Role of Social Media Marketing on Sustainable Performance of Firms' Operating in Multan, Pakistan. Sustainability 2019, 11, 3434. [CrossRef]

9. Green, T.; Peloza, J. How does corporate social responsibility create value for consumers? J. Consum. Mark. 2011, 28. [CrossRef]

10. Albuquerque, R.; Koskinen, Y.; Zhang, C. Corporate Social Responsibility and Firm Risk: Theory and Empirical Evidence. Manag. Sci. 2019, 65. [CrossRef]

11. Klosok-Bazan, I.; Machnik-Slomka, J. Crisis management in small water supply companies-problem with water quality. In Proceedings of the International Multidisciplinary Scientific GeoConference: SGEM, Albena, Bulgaria, 2-8 July 2018 ; pp. 179-185.

12. ISO. ISO 26000:2010(en); Guidance on Social Responsibility; ISO: Geneva, Switzerland, 2010.

13. Montiel, I. Corporate Social Responsibility and Corporate Sustainability. Organ. Environ. 2008, 21. [CrossRef]

14. Schwartz, B.; Tilling, K. 'ISO-lating' corporate social responsibility in the organizational context: A dissenting interpretation of ISO 26000. Corp. Soc. Responsib. Environ. Manag. 2009, 16. [CrossRef]

15. Carroll, A.B. A three-dimensional conceptual model of corporate performance. Acad. Manag. Rev. 1979, 4, 497-505. [CrossRef]

16. Gilmour, G.; Caplan, A. The Future of Corporate Reporting: Corporate Social Reporting_Who Cares? PricewaterhouseCoopers: London, UK, 2002.

17. Wild, J.J.; Wild, K.L.; Man, J.C.Y. International Business; Featuring a dynamic cross-cultural multimedia study tool; Pearson Education Inc.: London, UK, 2003.

18. Zu, L. ISO 26000. In Encyclopedia of Corporate Social Responsibility; Springer: Berlin/Heidelberg, Germany, 2013.

19. Griffin, R.W. Fundamentals of Management; Cengage Learning. Inc.: Florence, KY, USA, 2013.

20. Freeman, R.E.; McVea, J. A Stakeholder Approach to Strategic Management. In The Blackwell Handbook of Strategic Management; Blackwell Publishing Ltd.: Oxford, UK, 2017.

21. Monfardini, P.; Zimmerli, W.C.; Richter, K.; Holzinger, M. (Eds.) Corporate Ethics and Corporate Governance. J. Manag. Gov. 2009, 13. [CrossRef]

22. Hopkins, M. The Planetary Bargain: Corporate Social Responsibility Comes of Age; Macmillan Press: London, UK, 2003.

23. Foss, N.J.; Klein, P.G. Stakeholders and Corporate Social Responsibility: An Ownership Perspective. Aesthet. Style Strategy 2018, 17-35. [CrossRef]

24. Kramarz, M.; Knop, L.; Przybylska, E.; Dohn, K. Stakeholders of the Multimodal Freight Transport Ecosystem in Polish-CzechSlovak Cross-Border Area. Energies 2021, 14, 2242. [CrossRef]

25. Wolniak, R.; Wyszomirski, A.; Olkiewicz, M.; Olkiewicz, A. Environmental Corporate Social Responsibility Activities in Heating Industry-Case Study. Energies 2021, 14, 1930. [CrossRef]

26. Usman, A.B.; Amran, N.A.B. Corporate social responsibility practice and corporate financial performance: Evidence from Nigeria companies. Soc. Responsib. J. 2015, 11. [CrossRef]

27. Stojanovic, A.; Milosevic, I.; Arsic, S.; Urosevic, S.; Mihajlovic, I. Corporate Social Responsibility as a Determinant of Employee Loyalty and Business Performance. J. Compet. 2020, 12. [CrossRef]

28. Hąbek, P.; Wolniak, R. Relationship between Management Practices and Quality of CSR Reports. Procedia Soc. Behav. Sci. 2016, 220. [CrossRef]

29. Čierna, H.; Sujová, E. Integrating Principles of Excellence and of Socially Responsible Entrepreneurship. Manag. Syst. Prod. Eng. 2020, 28. [CrossRef]

30. Waldman, D.A.; Siegel, D.S.; Javidan, M. Components of CEO Transformational Leadership and Corporate Social Responsibility. J. Manag. Stud. 2006, 43. [CrossRef]

31. Xu, J.; Wei, J.; Lu, L. Strategic stakeholder management, environmental corporate social responsibility engagement, and financial performance of stigmatized firms derived from Chinese special environmental policy. Bus. Strateg. Environ. 2019, 28. [CrossRef] 
32. Akhter, F.; Kabir, M.R. Does Good Governance Make the Companies More Socially Responsible? Int. J. Bus. Technopreneurship 2018, 8, 125-136.

33. Wu, X.; Dluhošová, D.; Zmeškal, Z. Corporate Social Responsibility and Profitability: The Moderating Role of Firm Type in Chinese Appliance Listed Companies. Energies 2021, 14, 227. [CrossRef]

34. Klosok-Bazan, I.; Machnik-Slomka, J. Determinants of geothermal water deironing technology commercialization. In Proceedings of the International Multidisciplinary Scientific GeoConference Surveying Geology and Mining Ecology Management, SGEM, Albena, Bulgaria, 29 June-5 July 2017; Volume 17.

35. Van Beurden, P.; Gössling, T. The Worth of Values-A Literature Review on the Relation Between Corporate Social and Financial Performance. J. Bus. Ethics 2008, 82. [CrossRef]

36. Bijańska, J.; Wodarski, K. Model of Process Management System in Enterprises of the Hard Coal Mining Industry. Manag. Syst. Prod. Eng. 2020, 28. [CrossRef]

37. Balzarova, M.A.; Castka, P. Stakeholders' Influence and Contribution to Social Standards Development: The Case of Multiple Stakeholder Approach to ISO 26000 Development. J. Bus. Ethics 2012, 111. [CrossRef]

38. Pawlowska, E. Social Capital and the Efficiency of Public Organizations. In Proceedings of the 5th International Multidisciplinary Scientific Conference on Social Science and Art SGEM 2018, Business and Management, Sofia, Bulgaria, 8 November 2018; pp. 889-896.

39. El Akremi, A.; Gond, J.-P.; Swaen, V.; De Roeck, K.; Igalens, J. How Do Employees Perceive Corporate Responsibility? Development and Validation of a Multidimensional Corporate Stakeholder Responsibility Scale. J. Manag. 2018, 44. [CrossRef]

40. Walsh, J. Social Issues and Management: Our Lost Cause Found. J. Manag. 2003, 29. [CrossRef]

41. Shen, J.; Jiuhua Zhu, C. Effects of socially responsible human resource management on employee organizational commitment. Int. J. Hum. Resour. Manag. 2011, 22. [CrossRef]

42. Hąbek, P.; Pawłowska, E. Społeczna odpowiedzialność organizacji a kompetencje menedżerów. Przegląd Organ. 2009. [CrossRef]

43. Brammer, S.; Millington, A.; Rayton, B. The contribution of corporate social responsibility to organizational commitment. Int. J. Hum. Resour. Manag. 2007, 18. [CrossRef]

44. Klosok-Bazan, I. Innovations in industrial water preparation in a metallurgical plant. Metalurgija 2016, 55, 59-62.

45. Habek, P.; Wolniak, R. Factors Influencing the Development of CSR Reporting Practices: Experts' versus Preparers' Points of View. Eng. Econ. 2015, 26. [CrossRef]

46. Wei, Z.; Song, X.; Makhdoom, Z.H.; Xie, P. Paradox strategic cognition and ECSR in China: A three-tripod perspective. Asia Pac. Bus. Rev. 2019, 25. [CrossRef]

47. Bartkowiak, G. Społeczna Odpowiedzialność Biznesu w Aspekcie Teoretycznym i Empirycznym; Difin: Warszawa, Poland, 2011.

48. Czakon, W. Fundamentals of Research Methodology in Management Science (Podstawy Metodologii Badań w Naukach o Zarzadzaniu); Wydawnictwa Nieoczywiste: Warszawa, Poland, 2016. (In Polish)

49. Ticha, A.; Kocourkova, G.; Hrabincova, D.; Vazlerova. Water supply, sewerage and water price in the Czech Republic. In Proceedings of the 18th International Multidisciplinary Scientific GeoConference SGEM2018, Ecology, Economics, Education and Legislation, Albena, Bulgaria, 2-8 July 2018.

50. Hollweck, T.; Yin, R.K. Case Study Research Design and Methods (5th ed.). Thousand Oaks, CA: Sage. 282 pages. Can. J. Progr. Eval. 2016. [CrossRef]

51. Shen, C.-H.; Wu, M.-W.; Chen, T.-H.; Fang, H. To engage or not to engage in corporate social responsibility: Empirical evidence from global banking sector. Econ. Model. 2016, 55. [CrossRef]

52. Hąbek, P. CSR Reporting Practices in Visegrad Group Countries and the Quality of Disclosure. Sustainability 2017, 9, 2322. [CrossRef]

53. Sagan, A. Reliability analysis of satisfaction and loyalty scales (Analiza rzetelności skal satysfakcji i lojalności). StatSoft Pol. 2003, 39-52. (In Polish). Available online: https://www.researchgate.net/profile/Adam-Sagan/publication/2683 30390_ANALIZA_RZETELNOSCI_SKAL_SATYSFAKCJI_I_LOJALNOSCI/links/55ccce8108aebd6b88e05864/ANALIZARZETELNOSCI-SKAL-SATYSFAKCJI-I-LOJALNOSCI.pdf (accessed on 21 June 2021). 